\title{
Un programa iconológico perdido, recuperado. Pinturas de la iglesia nueva de Guadalupe, de Juan García de Miranda
}

\author{
M. ' TEResa JimÉnez
}

La iglesia nueva de Guadalupe constituyó uno de los conjuntos más reveladores, desde el punto de vista artístico, programático y significativo, de la influencia y ejercicio del patrocinio de un mecenas. Este conjunto es creado bajo los auspicios económicos e intelectuales de don Pedro Nuño Manuel Florentín Colón y Portugal, Duque de Veragua, Almirante y Adelantado de las Indias y virrey de Navarra, Sicilia y Cerdeña, además de ser ministro del monarca Felipe $V$.

Él concibe, elige y aprueba la arquitectura de la iglesia que encomienda en primer lugar a Vicente Alonso Torralba y posteriormente a Manuel de Larra Churriguera. La escultura de los retablos que habian de decorarla, tras estudiar una serie de proyectos, seria realizada por Felipe del Corral. Los lienzos que ornarian dichos retablos son escargados al pintor madrileño Juan García de Miranda.

En la elección de la construcción del edificio habria de participar también el prior del monasterio, mientras la escultura y pintura serian vigiladas directamente por el propio duque.

La iglesia, creada como ayuda de parroquia, fue erigida a ruego y por devoción del citado Duque de Veragua. La iglesia nueva, puesta bajo la advocación de la Santisima Trinidad, estaba situada en terrenos adyacentes a la iglesia-santuario de la Virgen de Guadalupe (Cáceres). Su fábrica respondia a unos cánones del barroco clasicista. Es un edificio sobrio y bien proporcionado que mide, sin incluir el grueso de sus paredes y pilastras, 140 pies de largo y 75 de ancho $(39,20 \mathrm{~m}$ y $21 \mathrm{~m})$; se estructuraba en tres naves, cubierta la central con bóveda de medio cañón con lunetos y las laterales con aristas, elevándose sobre el crucero la cúpula con 
linterna '. Ponz opinaba, basándose en sus criterios academicistas, que sus dimensiones y ornatos resultan extravagantes ${ }^{2}$.

El 18 de diciembre de 1739 tuvo lugar, con la solemnidad acostumbrada, la colocación de la primera piedra. Por fin el 1 de julio de 1734 se coronó con una cruz la media naranja de la iglesia, fecha que se ha tomado como final de la obra, a pesar de que ésta prosigue durante casi dos años más.

En 1731 al tomar la dirección de la obra Manuel de Larra Churriguera se ofrece para realizar los diecisiete retablos que el mecenas pensaba colocar como ornamento del edificio. Se acepta su proposición y se le encargan los dibujos de cuatro retablos distintos y proporcionados a las partes en que habian de ir situados, estimando su coste y los materiales a emplear. Los diseños le agradaron plenamente a don Pedro Nuño, ya que éstos fueron los que se ejecutaron; mas, por resultarle demasiado costoso, los presentó a otros maestros, siendo seleccionado para su talla, Felipe del Corral, que se comprometió a realizarlos por 12.000 ducados, con la única modificación de introducir columnas estriadas ${ }^{3}$.

El patrocinador de la iglesia falleció a principios de 1733 sin poder llegar a contemplar su obra terminada. Sin embargo el programa pictórico que habia ideado con anterioridad a su fallecimiento permaneció inalterable.

El pintor elegido para su realización fue, como hemos dicho, Juan Garcia de Miranda, con quien pudo tener contactos, dentro del ambiente cortesano, al trabajar el pintor en algunas obras para palacio y el Duque de Veragua ser ministro de Felipe V. Esta designación habla favorablemente de la categoria y aprecio en que se tenia a este artista, al seleccionarlo

' Archivo del Monasterio de Guadalupe. Legajo de Obras de la Iglesia Nueva. Escritura de Ajuste y Obligación de fecha 4 de febrero de 1730. Toda la documentación que utilizamos en este estudio es sólo una parte, por supuesto muy importante, de la hallada en este Monasterio y en el Archivo Histórico de Protocolos de Madrid, que nos ha servido para algunas publicaciones, como la de "Nuevas aportaciones sobre Manuel de Larra y Churriguerra", en B.S.E.A.A.V., 1974, págs. 343-367; "El escultor Felipe del Corral, en Extremadura", en Proserpina, 1986, págs. 126-135, y "Juan Garcia de Miranda, pintor de Cámara del rey Felipe V, en Guadalupe", Estudios Extremeños, 1976, 26 páginas. Por la importancia de este contrato, génesis de un programa iconológico no conocido e inusual, le dedicamos esta investigación.

${ }_{2}$ Ponz, A., Viaje, 2 ed. Madrid 1988, t. VII, carta 4, núm. 28, pág. 396. Opinión que no podemos compartir ante la evidencia de la grandiosidad, proporción y belleza existentes en la obra, planos y alzados.

${ }^{3}$ Archivo del Monasterio de Guadalupe. Legajo de Obras de la Iglesia Nueva. Carta del Duque fechada en Madrid, 30 de enero de 1733. Según escritura del 28 de marzo de 1733 realizada ante el escribano Juan Antonio de Arellano entre el artista y el duque. 
Un programa iconológico perdido, recuperado. Pinturas de la ...

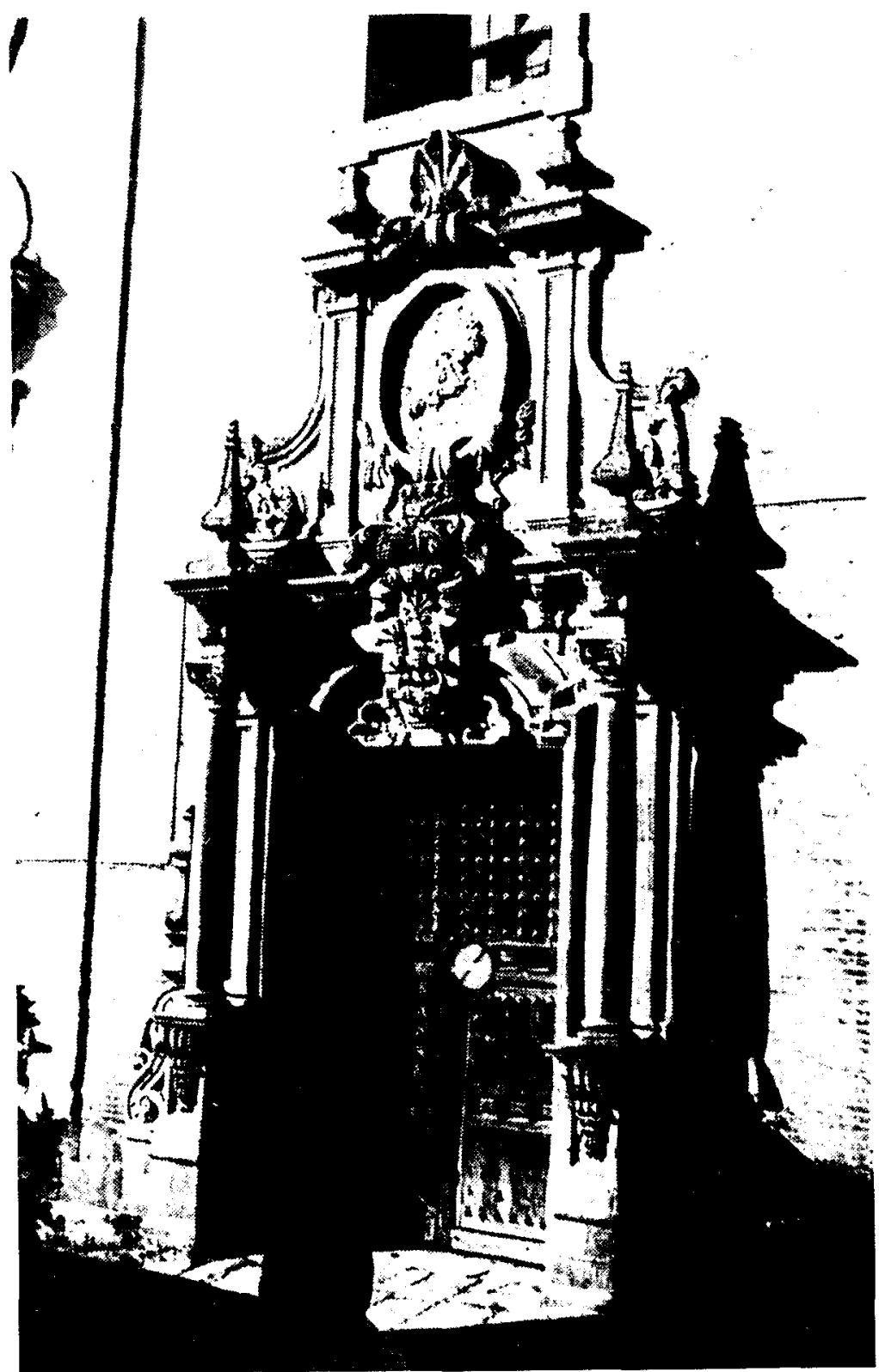

Fig. 1. Portada principal de la Iglesia Nueva de Guadalupe (Cáceres). 


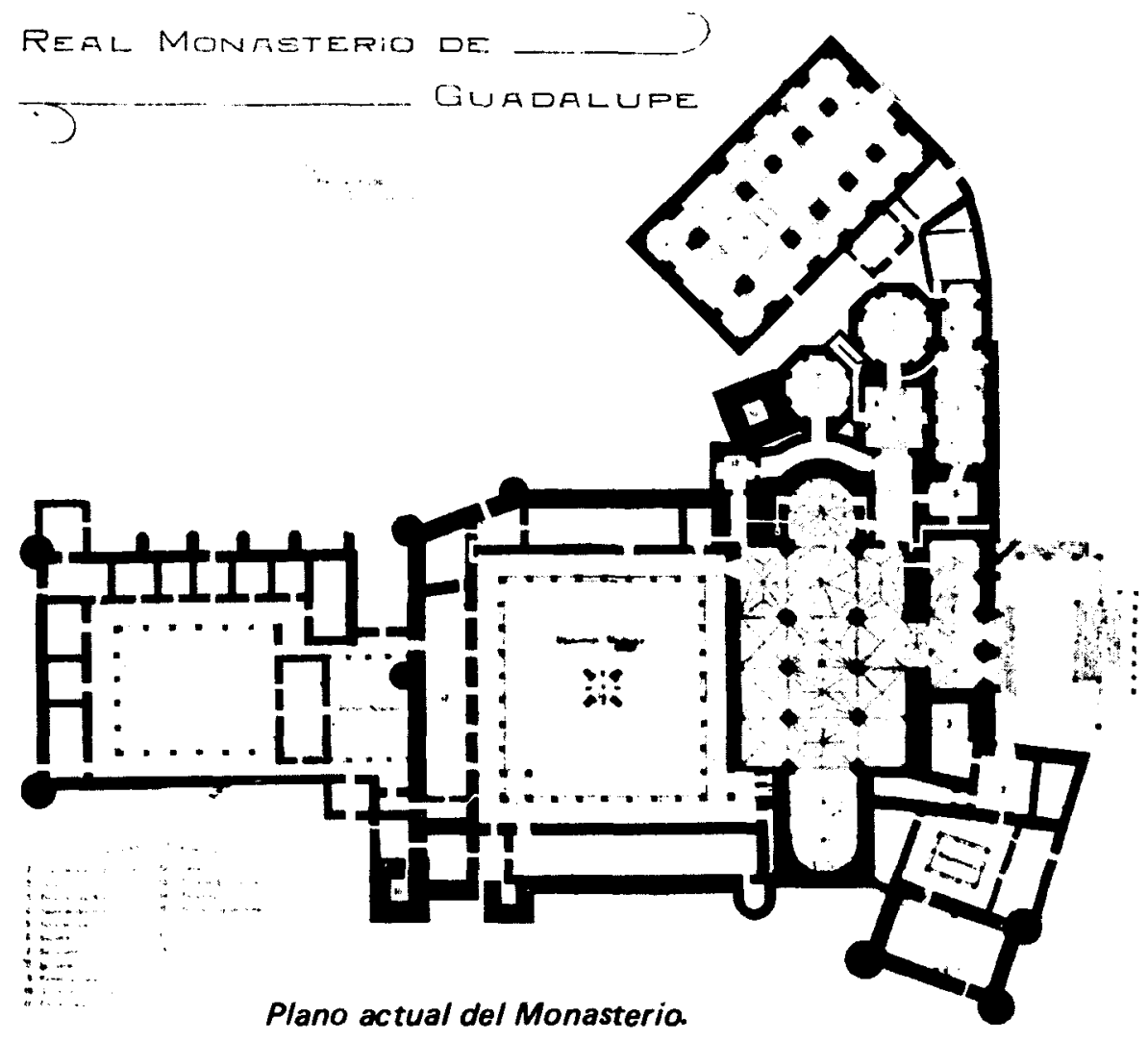

Fig. 2. Plano del Real Monasterio de Guadalupe con la Iglesia Nueva.

para dicha obra que en aquel momento tenía una gran importancia y prestigio, por el auge del propio monasterio y la calidad intelectual y artistica de la orden que lo regentaba, los jerónimos, muy vinculada desde su fundación a la corona.

No sabemos si el programa lo idearia el propio Duque, el monasterio, - religiosos y pensadores cercanos al mecenas. Lo cierto es que constituye un programa complejo, ambicioso y más conceptual que narrativo, no estando destinado a ser imágenes de "lectura" simple para el no iniciado. No hemos tenido la fortuna de identificar al mentor que realizaria aqui un papel similar al que el padre Sigüenza desempeñó en la Biblioteca del Escorial, el cual expresamente escribe que «la invención y la traza de las historias" son suyas. En ambos conjuntos las pinturas programáticas no son más que la exteriorización de las ideas. 


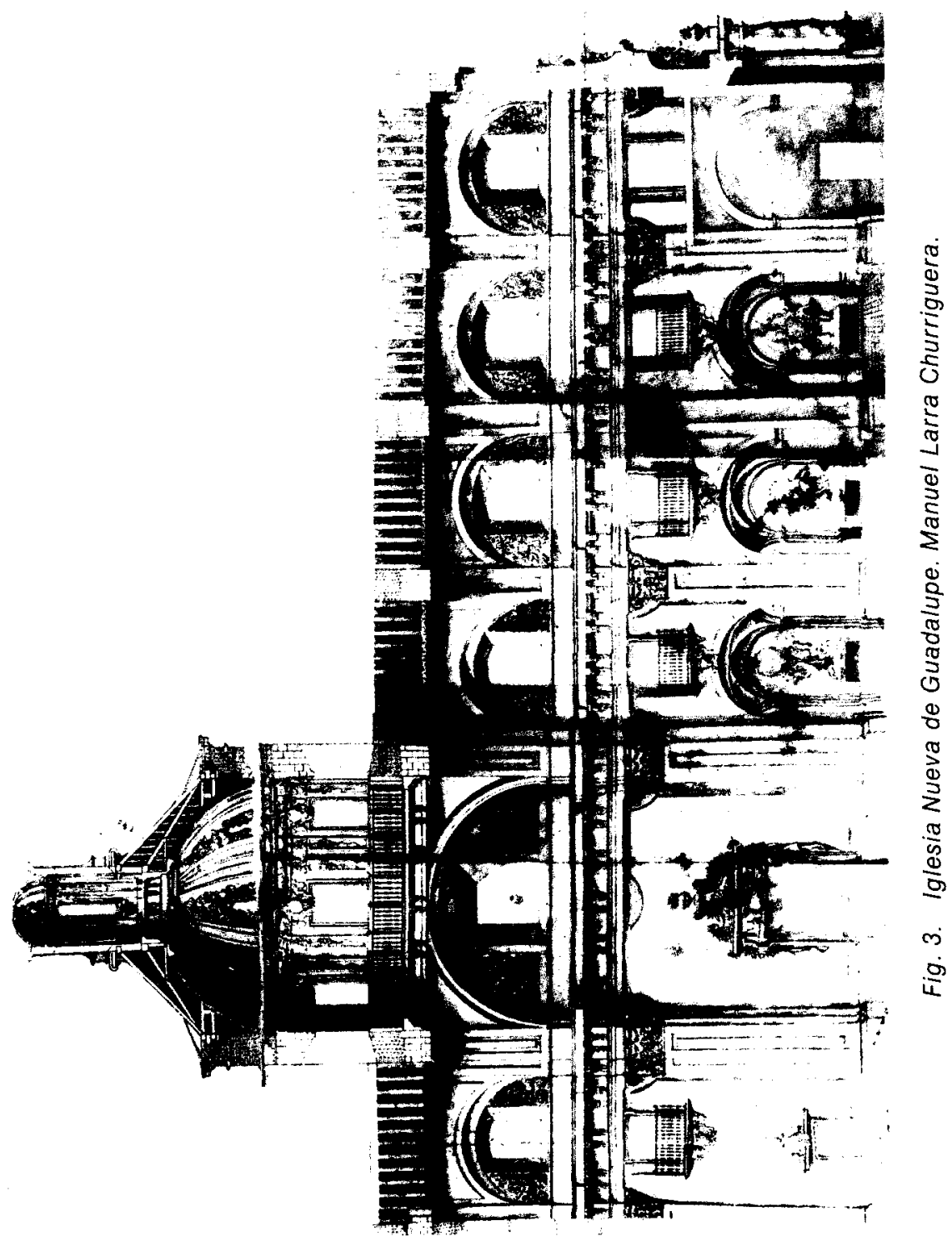


El conjunto pictórico que decoraba la iglesia nueva ofrece paralelismo con el que un siglo antes habia realizado Zurbarán en la sacristía de la iglesia del santuario. Ambos conjuntos tienen en común el estar pintados por un único artista, Juan Garcia de Miranda en el primero y Zurbarán en el segundo. Es patente la diferencia temática quizá debida a la época en que cada uno de ellos es realizado y en función del lugar donde están emplazados. En la sacristia se exalta la memoria de los sabios y santos jerónimos del siglo $x v$, época de máximo esplendor de la orden, dedicándose la capilla, al fondo de la sacristia, a la iconografia propia de San Jerónimo. El conjunto de la iglesia nueva cambia el carácter historiado por una temática conceptual vinculada a los nuevos ideales contrarreformistas.

Diecisiete grandes lienzos más tres tablas de menores dimensiones constituyen el conjunto que se distribuye por los diferentes paños interiores de la iglesia. En el altar mayor se emplaza el lienzo de mayores proporciones dedicado a la Trinidad, advocación titular de la iglesia por deseo expreso del comitente. También se incluyen en este retablo mayor tres escenas eucaristicas para las puertas del sagrario. A ambos lados del presbiterio se abren sendas capillas decoradas cada una con tres lienzos. En la del evangelio se contemplan: Nuestra Señora de Belén, el Ángel de la guarda y san Pedro penitente y lloroso; en el lado opuesto, el de la epístola, Los coros angélicos, el Purgatorio y en el último a Todos los Santos.

Llegados al crucero, en el lado del evangelio, se sitúa, próximo al presbiterio, La creación del mundo, y frontero a éste, Cristo en Sagrada Cena. Paralelamente, en el lado de la epistola se contemplan en disposición similar La encarnación de Cristo y Pentecostés.

Por otra parte, en las naves laterales del cuerpo de la iglesia se ubican desde el crucero hasta la puerta de la iglesia, en el lado del evangelio, los lienzos que ilustran los temas del: Monte Calvario, Descenso de Cristo a los infiernos y Cristo en la Gloria. Los otros tres cuadros correspondientes e iguales, que estaban frente a los mencionados, nos narran la Resurrección, Ascensión y Juicio Final.

El hueco del óvalo del altar mayor se decoraba con el escudo de armas de Nuestra Señora de Guadalupe: un jarrón con azucenas. La decoración pictórica se completa con la decoración de diecisiete frontispicios, "pintados en lienzos con sus bastidores de la medida regular de Altares para los diecisiete que ha de tener la dicha iglesia nueva" ${ }^{4}$, estos

\footnotetext{
${ }^{4}$ Archivo del Monasterio de Guadalupe. Legajo de Obras de la Iglesia Nueva. Escriptura
} 
Un programa iconológico perdido, recuperado. Pinturas de la ...

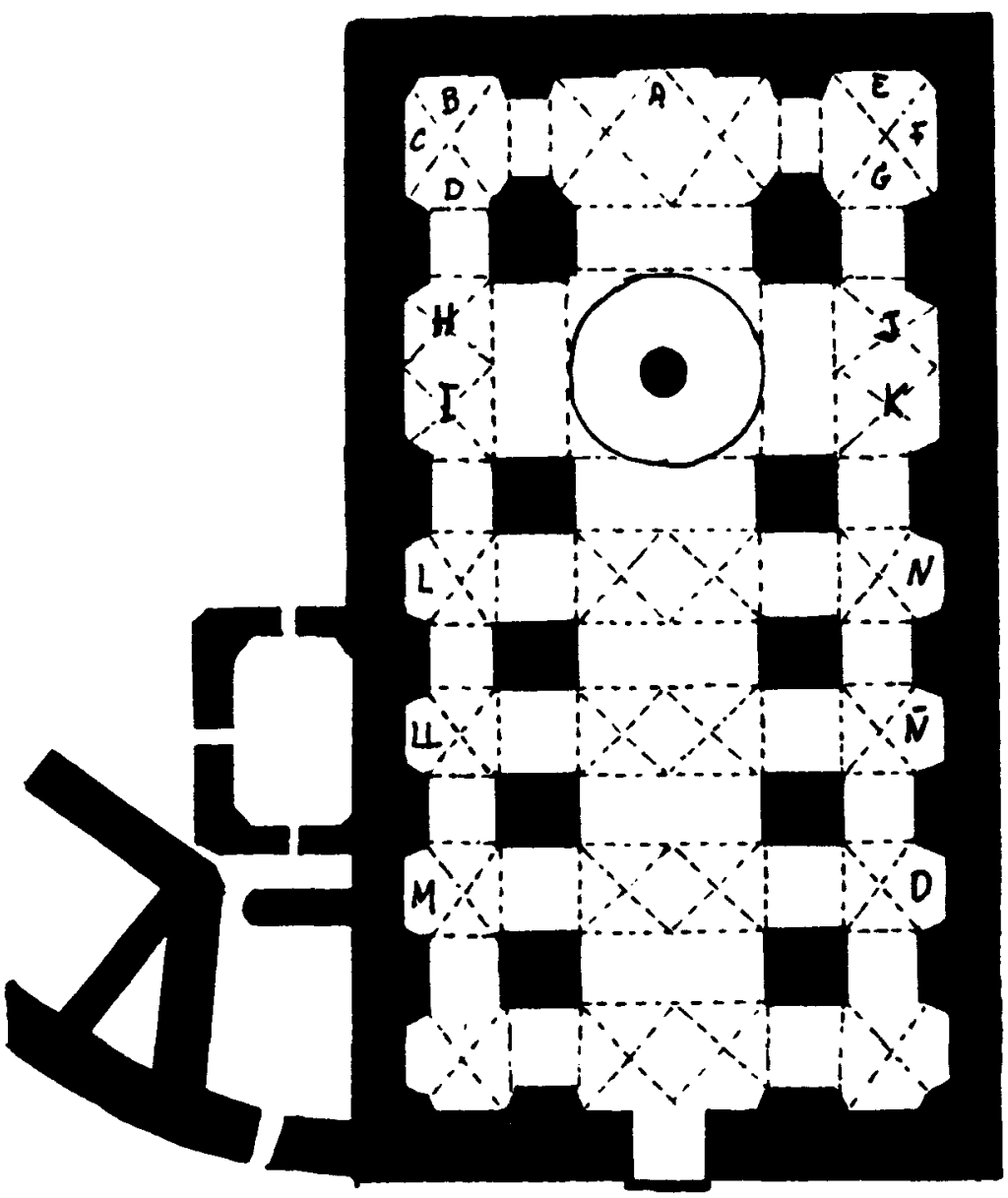

A. Trinidad (presbitero)
B. Ntra. Sra. de Belén
C. Angel Custodio
D. S. Pedro penitente
H. Creación del mundo
1. Santa Cena
L. Calvario

LL. Descenso al Limbo

M. Cristo en la Gloria

$\begin{array}{cl}\text { capillas } & \text { E. Coros angélicos } \\ \text { presbitero } & \text { F. Purgatorio } \\ & \text { G. Todos los Santos } \\ \text { crucero } & \text { J. Encarnación } \\ & \text { K. Pentecostés } \\ & \text { N. Resurrección }\end{array}$

cuerpo

iglesia

\section{N. Ascensión}

O. Juicio Final

Fig. 4. Esquema de la situación de las pinturas. 
frontispicios debian de ser pintados con flores y una tarjeta con el número o asunto del cuadro del altar respectivo.

Los cuadros tenian grandes dimensiones. El del altar mayor media más de 20 pies de alto por 12 de ancho $(5,60 \times 4,36 \mathrm{~m})$ y los del sagrario dos varas de alto y una de ancho $(1,77 \times 0,83 \mathrm{~m})$. Los seis cuadros de las capillas del presbiterio y los seis del cuerpo de la iglesia alcanzaban unas dimensiones de algo más de nueve pies de alto por algo más de seis de ancho $(2,52 \times 1,68 \mathrm{~m})$; por último los cuatro del crucero, de mayor tamaño que estos últimos, llegan a medir más de 15 pies de alto por nueve escasos de ancho $(4,20 \times 2,52 \mathrm{~m})$.

La ejecución de todas estas creaciones se habia de realizar por el importe de 26.120 reales de vellón, 20.000 por los lienzos de los retablos y 6.120 por los diecisiete frontispicios. Para su mayor brillantez se exige el uso de buenos colores finos, incluso laca y ultramarino.

"La operación de la Trinidad "ad extra"" es el título que sintetiza el contenido de estas diecisiete obras y su situación. Porque, en efecto, todo el programa pictórico responde a la advocación a la que está consagrada la iglesia: La Santísima Trinidad.

La Trinidad tiene dos operaciones: "ad intra", referidas a las relaciones interpersonales, por las que las Personas se crean, $y$ "ad extra", que constituyen la manifestación de cada una de ellas hacia el exterior. Así, la "operación» propia del Padre es la Creación, la del Hijo encarnado es la Redención, y la acción del Espíritu Santo es la expansión de la iglesia, cooperando en la redención. Ambas "operaciones" o "acciones" son plasmadas en este programa.

De acuerdo con estas premisas, la representación de la Trinidad se ubica en el escenario principal, el presbiterio. En él se plasman las Tres Personas con los atributos de la divinidad y eternidad, es decir, «la operación "ad intra"". Desde este solio imparten y realizan su "operación "ad extra"", la cual es referida en grandes composiciones en los altares del crucero y en los del cuerpo de la iglesia.

En la decoración de las dos capillas que lateralmente se abren al presbiterio se completa el programa iconológico, mostrándonos, en la del lado del evangelio, los medios que pueden ayudarnos en nuestra purificación y caminar; y en la del lado de la epistola se nos ofrece el término del proceso, el fin del ciclo de salvación.

de las pinturas de los cuadros de los retablos de la nueva iglesia. Madrid, 8 de agosto de 1733. Otra copia existe en el Archivo histórico de Protocolos, en Madrid, Legajo 13.927. 
Hemos de hacer notar también que "el programa" está imbuido y responde a las debatidas tesis contrarreformistas.

Para el cuadro que preside el altar mayor el mecenas da una serie de directrices como son "presentar a la Divinidad en figura de un Glouo sobre el que se señalarán unos caracteres hebreos que en esta lengua componen la palabra Dios; y en el medio del quadro ha de pintar las tres personas de la Santísima Trinidad, rodeadas de ángeles y con hermosas luzes de Gloria; también se yncluyen para este retablo maior tres pinturas pequeñas que han de seruir para la puertecilla del frente y de los dos costados del Sagrario del Altar Mayor las quales an de ser yguales en alto $y$ ancho de suerte que lo alto de cada una sean dos varas y su ancho de una; los assumptos de las tres puertas seran del Santissimo Sacramento de la Eucaristia respecto de circundarla en dicho Sagraio e ynteligenzia de que la pintura de el medio que hace frente bastará que este pintada por su exterior respecto de que no se ve su interior auiendose de bajar y subir por medio de un torno; pero la de los Costados aunque se suban y bajen ygualmente abran de tener por la parte interior algun adorno de flores y Angeles para que cuando su Diuina Magestad este presente se vean dhos adornos de flores y Angeles y la puertezilla del Sagrario del Copón con el Buen Pastor y en el hueco del obalo del Altar maior el escudo de armas de Ntra. Sra. de Guadalupe" ${ }^{5}$.

Dada la época, el pensamiento y la localización, asi como la finalidad a la que iba destinada, hemos de presumir que no incurria en ninguno de los errores que Pacheco y otros tratadistas como Molano, Martín de Roa, etcétera. consideran como impropios de tal representación. Por tanto podria estar próxima a las imágenes creadas por Durero ${ }^{6}$, El Greco ${ }^{7}$, José Jiménez Donoso ${ }^{8}$, Anónimo español del siglo xvill conservado en el Museo del Prado ${ }^{9}$, que se ajustan muy de cerca a las formas de representación propiciadas por Pacheco, consistentes en Dios Padre en figura de un grave y hermoso anciano, Cristo de edad de treinta y tres años con bello rostro y desnudo con sus llagas visibles en pies, manos y costado, acompañado de la cruz o algunos de los instrumentos de la pasión. El Espiritu Santo se acostumbra a figurarlo en forma de paloma. Suele

${ }^{5}$ Ibidem. Cuando se cite en el texto algún fragmento entrecomillado y no explicitemos su origen nos estamos refiriendo al documento mencionado en la nota 4.

${ }^{6}$ La Trinidad, grabado de hacia 1511.

7 Trinidad, óleo sobre lienzo, $300 \times 179 \mathrm{~cm}$, Museo del Prado, Madrid, núm. de inv. 82.4

${ }^{8}$ Triunfo de la Santisima Trinidad, óleo sobre lienzo, $666 \times 390 \mathrm{~cm}$, Museo del Prado, Madrid, núm. inv. 5.629 .

${ }^{9}$ La Trinidad, óleo sobre tienzo, $119 \times 89 \mathrm{~cm}$, Museo del Prado, Madrid, depositado en la iglesia de San Jerónimo el Rea! de Madrid desde 1883, núm. de inventario 3.267. 


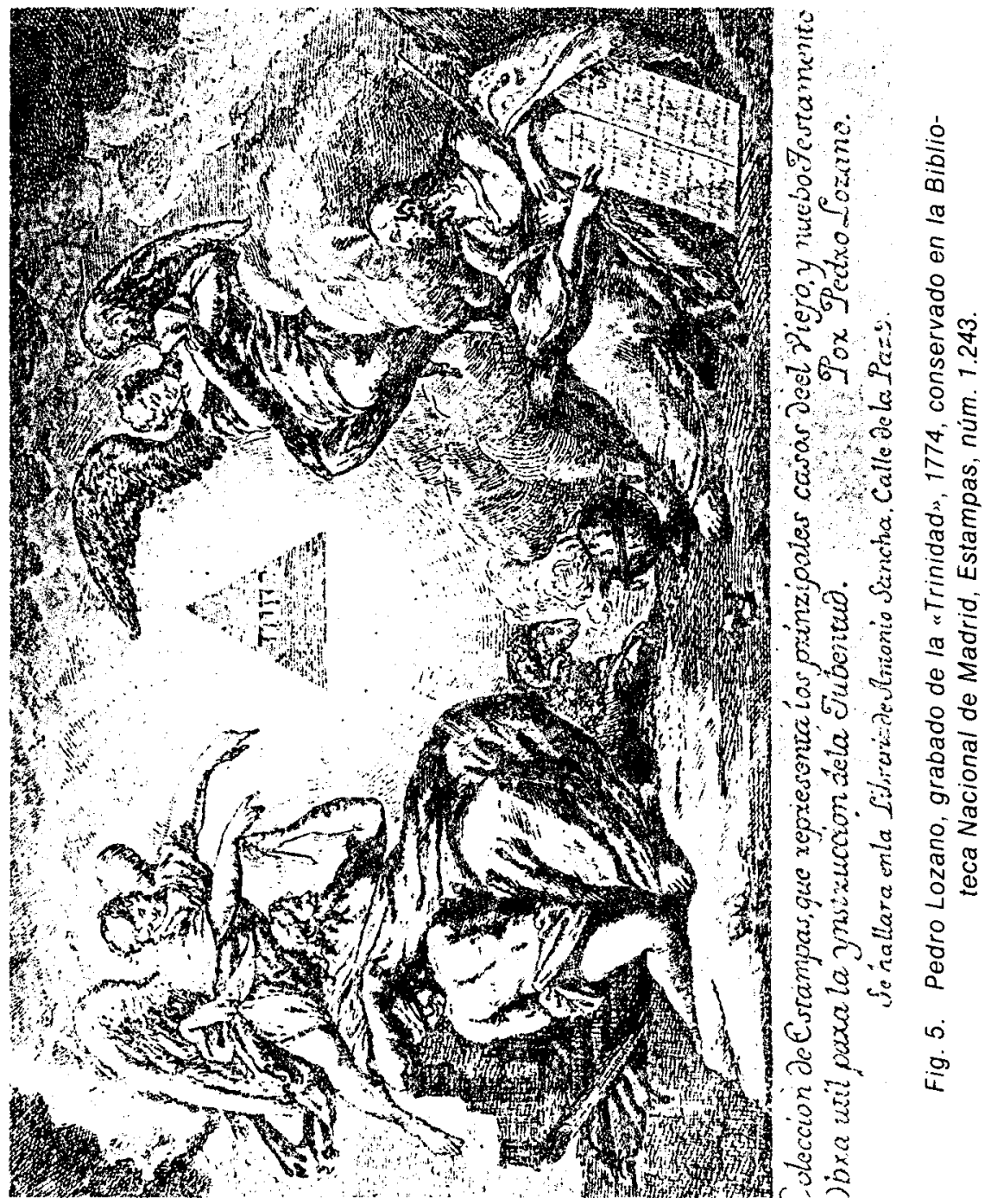


acompañarles un circulo de resplandor que denota que Dios no tiene ni principio ni fin ${ }^{10}$.

En los cuatro lienzos del «crucero" se inicia el ciclo de la "operación "ad extra"” de la Trinidad. Su «lectura" puede hacerse siguiendo un orden de contiguos $u$ opuestos, laterales o frontales. La Creación y la Cena inician dos momentos "vitales", y la Anunciación y Pentecostés aluden a dos venidas del Espíritu. En otro sentido, la Creación y la Anunciación contraponen a las dos Evas, la Antigua y la Nueva Eva, la que perdió la vida y la que de nuevo la aporta. La Cena de Cristo y Pentecostés constituyen las fuerzas que el hombre puede recibir para aliviar su camino.

En el brazo correspondiente al lado del evangelio, contemplamos la pintura de la Creación. Sobre ella indica el duque que se han de figurar «Adán y Eva de un modo acordado y natural de forma que estén dezentes y el padre Eterno se figurará como entre nubes bien dispuestas y como que los está mirando. $Y$ todo lo demás que sea correspondiente a la referida Creación». La creación de Adán y Eva simboliza la aparición de la vida humana y alude también al pecado original y al inicio del proceso redentor. El que se indique que Adán y Eva han de estar representados de manera decente, es un reflejo de una de las principales preocupaciones contrarreformistas, donde el interés reside en que estén efigiados acorde con su categoria y evitando los desnudos innecesarios y otras incorrecciones iconográficas ${ }^{11}$.

Esta escena es representada por Ghiberti en las Puertas del Paraíso del baptisterio de Florencia, Rafael en los loggias del Vaticano, Miguel Ángel en la capilla Sixtina, Jacoppo della Quercia en las puertas de San Petronio en Bolonia.

E! segundo cuadro situado en este lado del crucero representaba a "Cristo en la zena con sus Apostoles, cuando instituio el Sacramento de la Eucaristia, teniendo el pan en su mano derecha y con la vista al Zielon. La Eucaristia representa el sacramento por excelencia, éste fue rehusado por ciertas sectas protestantes y otras querían reducir el papel de Dios en él, lo cual motivó un cambio iconográfico del tema de la Santa Cena.

10 Interian de Ayala, J., El pintor erudito y cristiano. Barcelona 1883, t. I, 55 y 110; Reau, L., Iconographie de l'art chrétien. Paris 1956, II, 1, págs. 14 29; HALL, J., Diccionario de temas y simbolos artísticos. Madrid 1987, págs. 301-302; ReviLLA, F., Diccionario de iconografia. Madrid 1990, págs. 367-368; PACHeCO, F., Arte de la Pintura, 1638, ed. de B. Bassegoda. Madrid 1990, págs. 562-566.

1 Reau, L., op. cit., II, 1, págs. 65-93; Champeaux, Gèrard de y Sterckx, Sébastien, Introducción a los simbolos. Madrid 1984, págs, 481; HALL, J., op. cit., pág. 93; PACHECO, F., op. cit., págs. 291-307. 


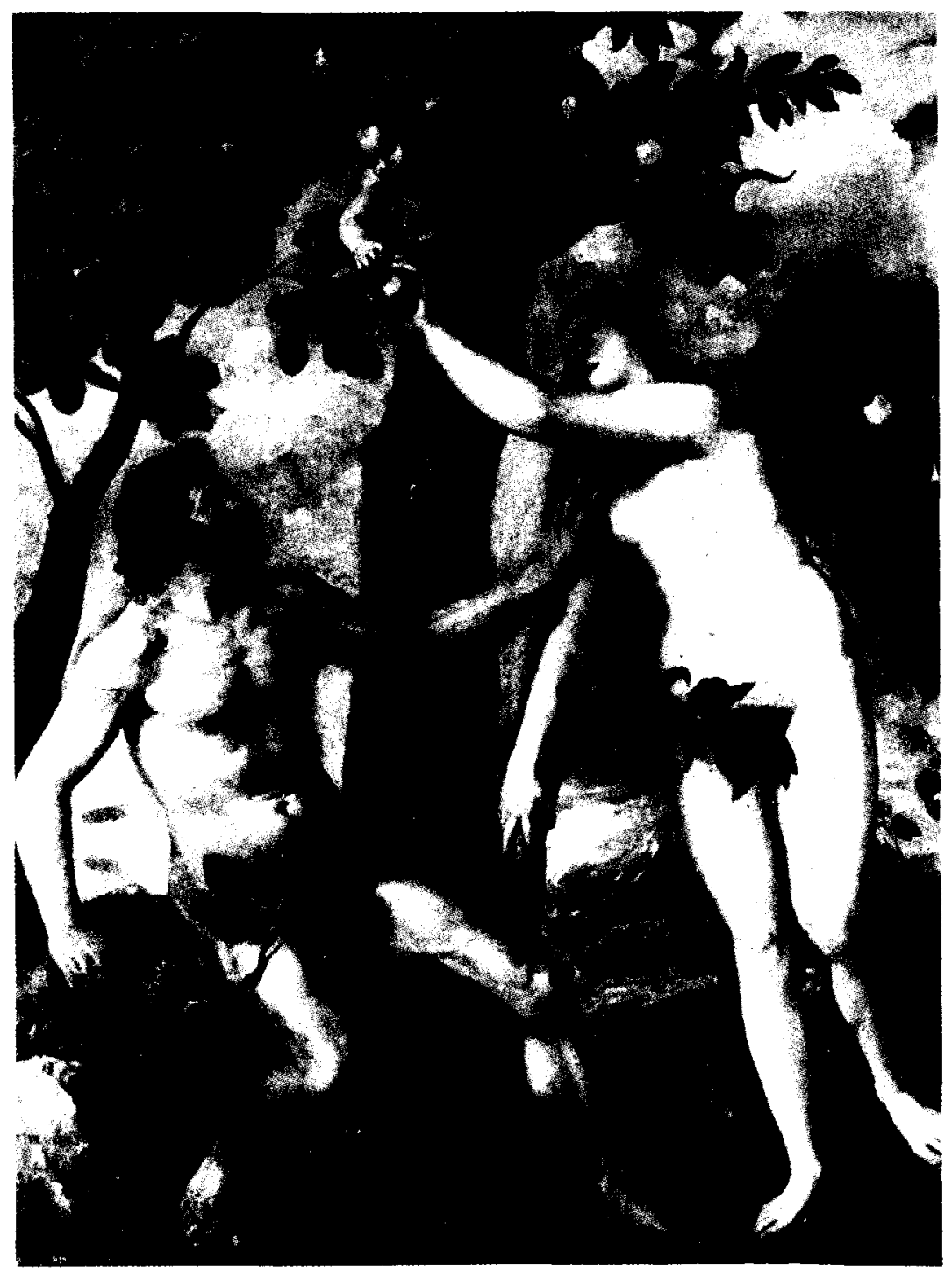

Fig. 6. Tiziano, “Adán y Eva”, Museo del Prado, Madrid.

Desde los origenes del arte cristiano y durante casi toda la Edad Media, los artistas pintaron el momento en que Jesús pronunciaba la frase "Uno de vosotros me traicionará», y no el instante en que decia "Este es mi cuerpo". Es a lo largo del siglo xv cuando bajo la influencia del teatro se presenta a Jesús consagrando el pan y el vino entre los apóstoles. De 
hecho el famoso cuadro de Leonardo recoge el momento de la traición, pero a consecuencia de la tormenta protestante en la segunda mitad del siglo xvi, este modelo es sustituido por el de la institución de la Eucaristía, tratando de afirmar lo que se duda o discute, venerando aquello que niega la herejia y haciendo hincapié en los principios que la iglesia católica defiende. Tambièn marca el inicio del ciclo de la pasión ${ }^{12}$.

Esta escena fue representada con estas caracteristicas por Rubens ${ }^{13}$, Juan de Juanes ${ }^{14}$ y pocos más.

Paralelamente, en el lado de la epistola, se situaba el lienzo de La encarnación de Cristo, el único del cual se conserva el original, y que hoy decora la entrada del cuerpo de la iglesia del Santuario. Las directrices para su realización son las siguientes: "La Encarnación de Jesús con el Padre Eterno en lo alto y entre la distancia o espacio que ha de auer entre el Padre Eterno a la Virgen Santisima figurará el Espíritu Santo, despidiendo sobre Su Magestad que estará de rodillas, muchos raios de luzes y el Ángel en su postura de Diuino Embajador". El lienzo conservado responde escrupulosamente a estos criterios.

Mâle, en su libro sobre el arte de la contrarreforma, describe la escena de la Anunciación y su génesis artística de la siguiente forma: "En el arte de fines de la Edad Media, la Anunciación tomaba un carácter de conmovedora intimidad. En Flandes, la Virgen reza en una pequeña habitación inmaculada, en la que los cobres brillan tanto como el oro, en la que un lirio florece en un bello vaso; el ángel ha entrado sin ser visto por la puerta entreabierta y está de rodillas. En este silencio, entre los objetos humildes y familiares, va a decidirse el destino del mundo. Italia embellece la habitación con una guirnalda antigua, o la abre, a veces sobre los laureles de un jardin, o al horizonte de la Umbría, pero conserva el carácter intimo de la escena.

La Anunciación del siglo XVII contrasta vivamente con su antecesora. El cielo invade de golpe la celda en la que reza la Virgen, y el ángel, con un lirio en la mano penetra en ella arrodillado en una nube. Vapores de luz y sombra hacen desaparecer a menudo el lecho, el hogar, los muros, todo lo que recuerda las realidades de la vida. Parece que dejamos de estar en la tierra para trasladarnos al cielo. Casi siempre otros ángeles hacen cortejo al mensajero celeste y es muy raro que algunos rostros

12 Interian de Ayala, J., op. cit., t. I, págs. 364-367; Reau, L., op. cit., II, 2, págs. 406-426; Male, E., El Barroco. Madrid 1985, págs. 90-95; Revilla, F., op. cit., 148; Hall, J., op. cit., págs. 306-307.

${ }_{13}$ Jesucristo consagrando el pan y el vino, óleo sobre lienzo, Pinacoteca Brera, Milán.

${ }^{14}$ Santa Cena, oleo sobre lienzo, $116 \times 191 \mathrm{~cm}$, Museo del Prado, Madrid, núm. inv. 846. 


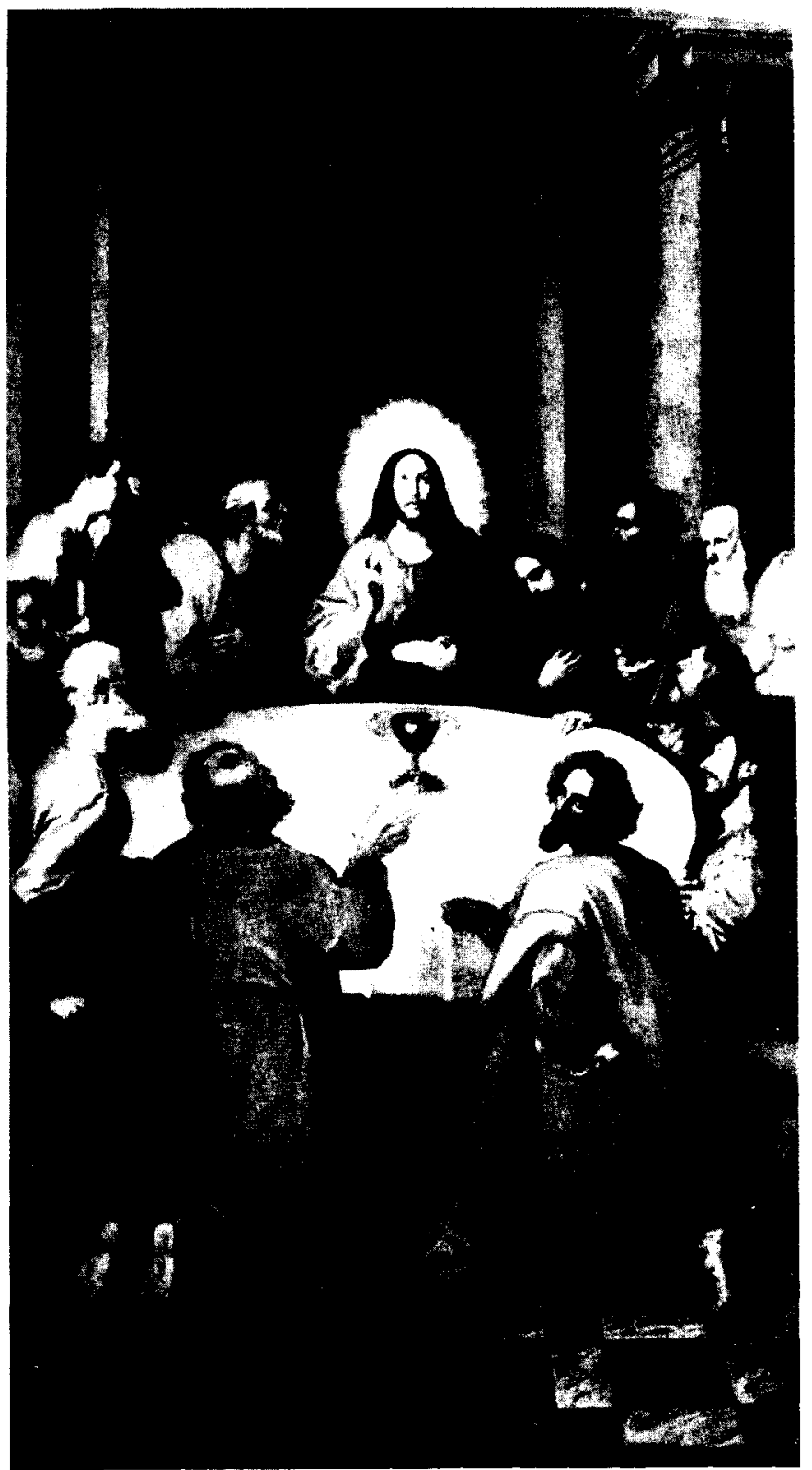

Fig. 7. Ribalta, "Santa Cena", Colegio del Patriarca, Valencia. 
graciosos dejen de aparecer entre las sombras. El arte ha querido, pues, poner la tierra en relación con el cielo. Parecia como si la Virgen de antaño, aislada en su celda, no tuviese ni la suficiente grandeza ni el suficiente misterio, era necesario hacer comprender que los ángeles y el propio dios esperaban su respuesta" ${ }^{15}$. A menudo los libros de devoción señalan la presencia de los ángeles en la Anunciación.

El Espiritu Santo aparece representado, como es habitual, en forma de paloma y el ángel porta en su mano derecha la rama de lirios, símbolo tradicional de la pureza de María y que en la concepción de Pacheco ${ }^{16}$ significa la exaltación de la Virgen de un estado humilde al más alto y elevado de Reina del cielo y Madre de Dios. La decoración se reduce al reclinatorio donde la Virgen reza y lee las sagradas escrituras. En general el lienzo responde a los preceptos recomendados por el tratadista mas sin acusar el momento en el que tuvo lugar este misterio, bien sea porque el artista no lo observase o bien se deba al oscurecimiento que el lienzo ha sufrido por los avatares y poco cuidado en su conservación.

Podiamos asimismo establecer un parangón entre esta Anunciación de Juan García de Miranda, realizada entre 1733 y 1735, y su versión fechada en 1723 que se custodia en la iglesia de San Lorenzo, de Valladolid. La primera impresión es de una gran sorpresa al contemplar que el artista ha repetido la misma composición en ambos lienzos, si bien más simplificada en el de Guadalupe, pues en la vallisoletana ha incluido también la presencia de Dios Padre. Como la obra de Valladolid ha sido recientemente restaurada la observación de todos los detalles, estudio de luces, etcétera, puede ser perfectamente realizado.

Tanto una como otra se ajustan a los principios de decoro y a las normativas contrarreformistas descritas por Pacheco y otros tratadistas del momento.

Otros artistas que han abordado este tema son El Greco, con el que presenta analogía en el tratamiento del ángel y en la sensación de movimiento ${ }^{17}$, Ignar Günther ${ }^{18}$, Murillo ${ }^{19}$, Pantoja de la Cruz ${ }^{20}$, etc.

El cuarto cuadro del crucero se dedica a Pentecostés, indicando el comitente que en él se representará la venida del Espíritu Santo en lenguas

${ }^{15}$ MaLe, E., El Barroco, op. cit., págs. 204-206.

${ }^{16}$ PaCHeCO, F., Op. cit., págs. 592-595. También tratan este tema Reau, L., op. cit., II, 2 , págs. 174-194; HALL, J., op. cit., págs. 40-41; REVILLA, F., op. cit., págs. 35-36.

17 Oleo sobre lienzo, $315 \times 174 \mathrm{~cm}$, Museo del Prado, Madrid, núm. inv. 3.888 .

${ }^{18}$ Anunciación. Museo Nacional de Baviera, siglo xvIII, escultura de 1764.

${ }^{19}$ Óleo sobre lienzo, hacia 1672-1676, Museo de Bellas Artes de Sevilla.

${ }^{20}$ Óleo sobre lienzo, $227 \times 142 \mathrm{~cm}$, Museo del Prado, Madrid, núm. inv. 4.800 


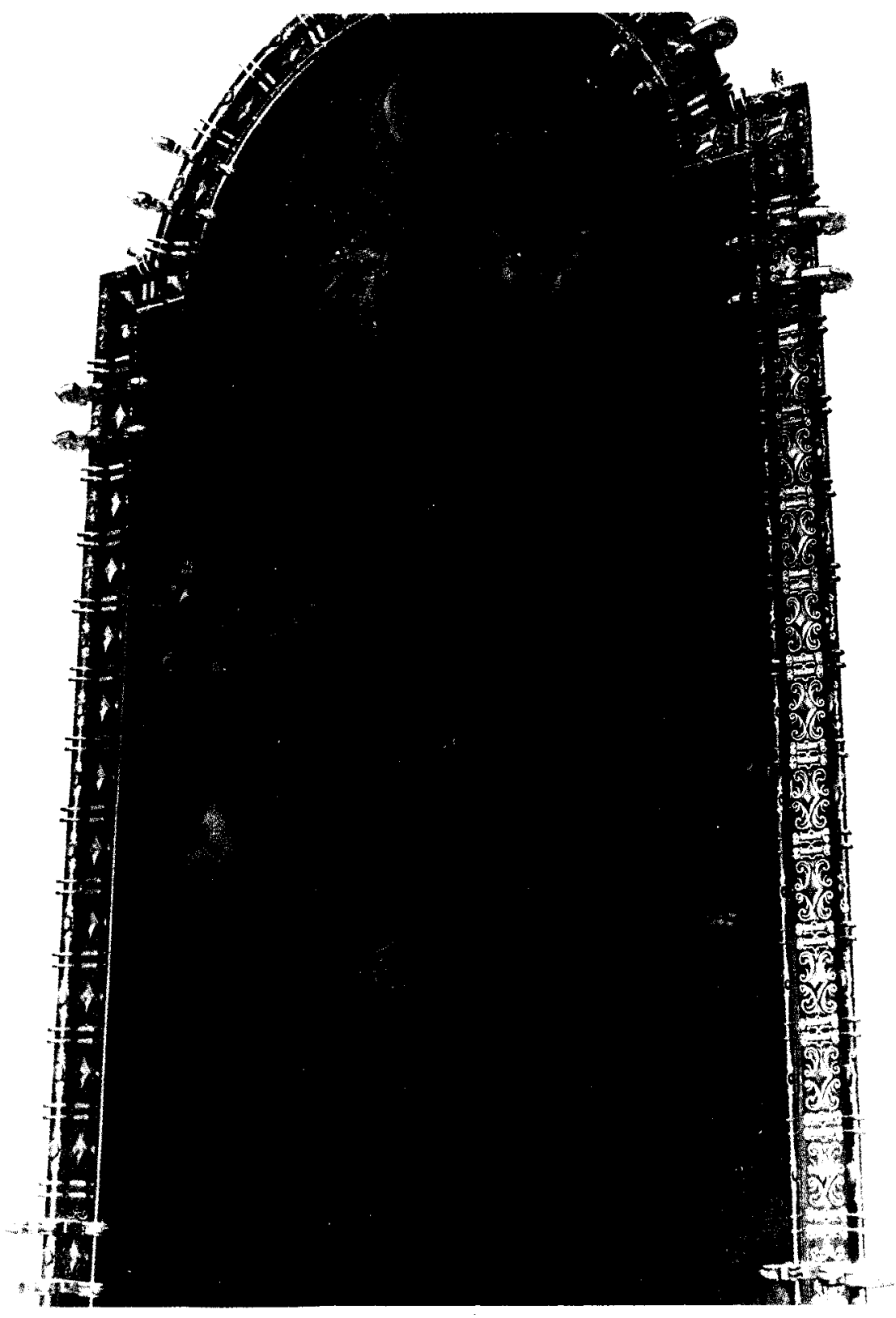

Fig. 8. Juan Garcia de Miranda, "La Anunciación», Iglesia Santuario del Monasterio de Guadalupe. 
de fuego sobre los Apóstoles, estando en el cenáculo y María Santísima en medio de ellos". Por tanto la escenificación se ajusta a lo descrito en la Biblia, donde en los Hechos de los Apóstoles (2: 1-4) se narra que éstos de nuevo en Jerusalén, tras haber contemplado la Ascensión de Cristo, y estando reunidos en una habitación, para celebrar la fiesta judia de Pentecostés, orando sienten "de repente un ruido del cielo, como de viento recio (que) resonó en toda la casa donde se encontraban, y vieron aparecer unas lenguas como de fuego posándose encima de cada uno. Se llenaron todos de Espiritu Santo y empezaron a hablar en diferentes lenguas, según el Espiritu les concedía expresarse». En opinión de James Hall ${ }^{21}$ este tema es poco frecuente en el arte cristiano posterior a la Edad Media, de ahi la importancia de esta representación de la que nos ocupamos a la que se añade el complemento de ser un hito importante en el nacimiento de la Iglesia.

La iconografia más habitual es la que consiste en tratarla de un modo compositivo similar al de la Cena, salvo que en esta ocasión, el puesto central, en vez de Jesucristo, lo ocupa la Virgen, en su papel de madre de todos los hombres y de la Iglesia en particular. A su alrededor se distribuyen los doce apóstoles, pues el lugar de Judas habia sido ocupado por Matias, que pueden efigiarse, o sentados alrededor de la mesa, o bien levantándose repentinamente al presenciar el acontecimiento. En lo alto suele incluirse una doble representación del Espiritu Santo que está presente por medio de la paloma y a través de las lenguas de fuego que se pintan sobre las cabezas de los apóstoles para ilustrar el acontecimiento. El lienzo de Juan Garcia de Miranda no se debia distanciar mucho de esta clásica composición tradicional, que vemos en obras de El Greco ${ }^{22}$, Juan Bautista Maino ${ }^{23}$. Antonio Palomino ${ }^{24}$, etc.

Este acontecimiento simboliza la universalidad dentro de la Iglesia y tiene implícito un alto grado de expresión del sentido de la reconciliación del mundo con su Creador, y más concretamente del hombre. Todo esto, como veremos a continuación, nos ayuda a comprender el programa iconográfico y simbólico aquí representado.

En este crucero, la primera escena correspondia al momento de la creación del mundo y el hombre por Dios, que es el punto de partida

\footnotetext{
${ }^{21}$ Hall, J., op. cit., págs. 310-311. Interian de Ayala, J., op. cit., págs. 474-476; Reau, L., op. cit., II, 2, 591-599.

${ }_{22}$ Pentecostés, óleo sobre lienzo, $275 \times 127$, Museo del Prado, Madrid, núm. inv. 828.

${ }^{23}$ Pentecostés, óleo sobre lienzo, $285 \times 163 \mathrm{~cm}$. Museo del Prado, Madrid, núm. de inv. 3.018

${ }^{24}$ La venida del Espiritu Santo, óleo sobre lienzo, $164 \times 108 \mathrm{~cm}$, Museo del Prado, Madrid, núm. inv. 2.964
} 


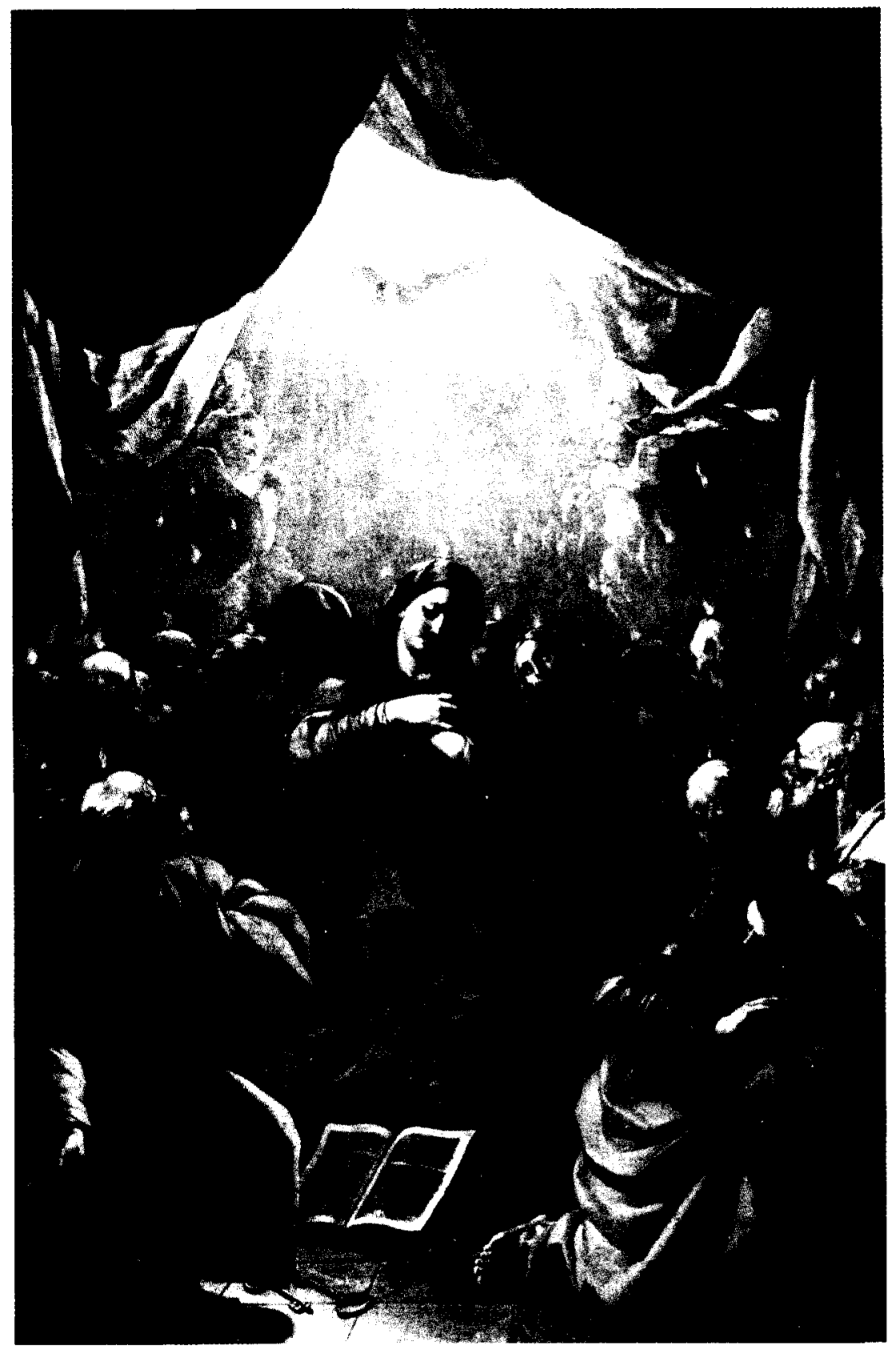

Fig. 9. Palomino, "Pentecostés", Museo del Prado, Madrid. 
desencadenante de los acontecimientos posteriores: pecado original e historia de la redención. La historia de la redención se inicia en el mismo momento de cometerse el pecado original, cuando Dios promete al mundo un Salvador, su propio Hijo. Precisamente, al cumplimiento de esta promesa corresponde la escena de la Anunciación, del segundo lienzo, cuando Dios escoge el vientre de Maria para albergar en él a su Hijo. El deseo divino se hace presente a través de dos emisarios, uno el ángel San Gabriel, y otro la tercera persona de la Trinidad, el Espíritu Santo, constituyendo este momento la primera venida del Divino Espiritu en forma visible. Esta primera venida nos servirá de nexo de unión con el cuarto lienzo, el de Pentecostés, donde de nuevo y por tercera vez, a lo largo de todo el Nuevo Testamento, se hace presente de forma visible para dar ánimos y reconfortar a los apóstoles, de la misma forma que lo había hecho con María, participando de forma activa en la constitución y desarrollo de la acción evangelizadora. Otra relación se puede establecer también a nivel conceptual entre estas dos obras. Si en la primera es Dios quien delega la misión salvadora en Cristo, dando origen a su concepción y posteriormente a su nacimiento, en Pentecostés, ha sido Cristo quien ha delegado esta misión en los apóstoles, y una vez ascendido a los cielos les envia el Espiritu Santo para que sigan teniendo constancia del auxilio divino.

Por su parte, el tercer lienzo, que podria parecer desvinculado del resto del conjunto, tiene gran relevancia y significación, pues la Cena simboliza la institución de la Eucaristía, y por tanto lleva implícito en si el sacramento de la Penitencia, incluso se insiste de nuevo en el perdón y reconciliación de Dios con el hombre. Pero además la Eucaristía es el acontecimiento en torno al cual gira y se justifica primordialmente toda la liturgia y constituye el inicio de la via de salvación del fiel, quien solamente a través de la práctica de los sacramentos y la lectura de los textos sagrados puede salvarse. Este carácter redentor y universal estaria aludido por la presencia en el primer lienzo de Adán y Eva, los padres de la humanidad.

Si con la Creación de Adán y Eva, se iniciaba el ciclo de la historia de la Humanidad, con la Anunciación se señalizaba el paso del Antiguo Testamento, la oscuridad, al Nuevo Testamento, la Luz; con la Última Cena, se expresaba el inicio de la Pasión y por tanto de la Redención, el proceso se cierra en Pentecostés con la representación de un acontecimiento glorioso. Por tanto de una manera sutil, muy elaborada y pensada, se está aludiendo, precisamente a la Iglesia triunfante, que, en estos momentos de lucha contrarreformista, es la Iglesia Católica. 
Junto a este programa se encuentra otro ciclo complementario, situado en los altares del "cuerpo" de la iglesia, donde se describe la historia de la muerte y resurrección de Cristo y el subsecuente Juicio Final, culminando todo él con la representación de Cristo glorioso. Todas estas escenas, aparentemente, tienen un fuerte contenido evangelizador hacia los fieles, dado que, conociendo los Libros Sagrados, se reconocen las historias; pero su sentido iconológico, el por qué de esas escenas y su sucesión, quedaba reservada a una docta minoria. Por otra parte, este aspecto simbólico e iconológico era exigido por el carácter funerario de la propia iglesia, dedicada a lugar de enterramiento ${ }^{25}$.

El programa iconográfico desarrollado a lo largo del cuerpo de la iglesia, ha de ir leyéndose de forma sucesiva, siguiendo la disposición longitudinal de las naves, pero en zig-zag, de forma alternante de izquierda a derecha. El ciclo narrativo de esta parte de la iglesia se inicia en el Calvario y finaliza, en los pies, con el Juicio Final.

El tema del Calvario, tiene por protagonista la muerte de Cristo. Durante algún tiempo la representación artística de este acontecimiento servia como pretexto para llenar la composición de personajes; sin embargo,

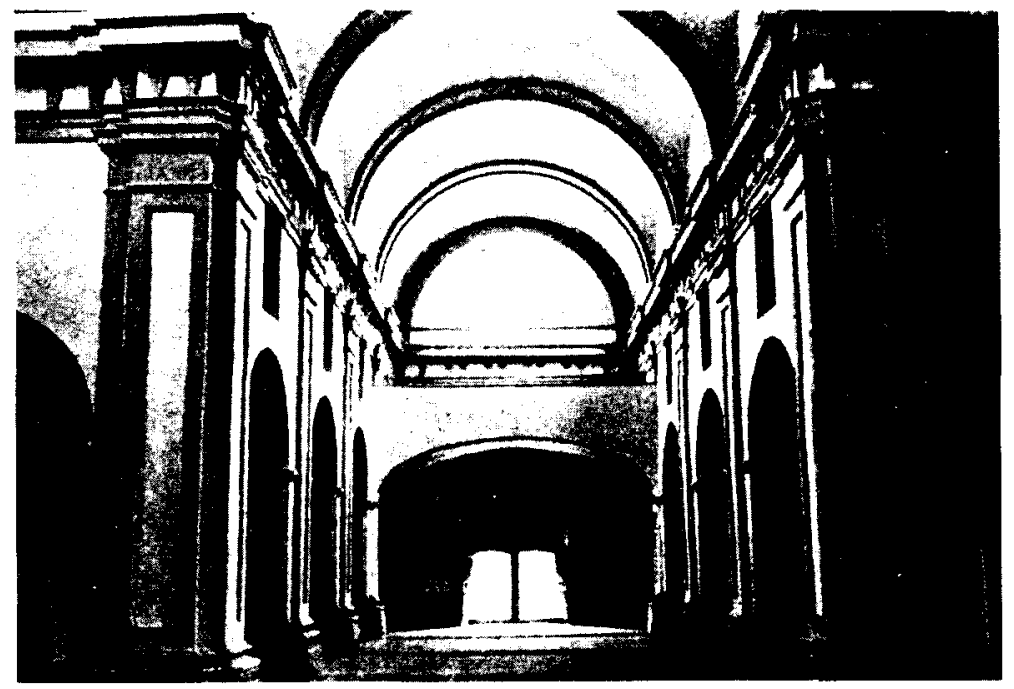

Fig. 10. Aspecto del cuerpo de la Iglesia Nueva.

${ }^{25}$ Madoz, P., Guadalupe 1847, edic. Zafra, 1991, t. IX, págs. 27-29; Trenado, F., “La iglesia nueva de Guadalupe convertida en auditorium», Guadalupe, Año LXII, núms. 637-638, septiembre-diciembre 1978, págs. 275-279. 
pronto se supera esta imagen y se crea la que estamos acostumbrados a contemplar y que seria la admitida y consagrada después del Concilio de Trento. Responde a la narración histórica y sólo la integran los componentes esenciales, que, como Réau ${ }^{26}$, podiamos agruparlos en personajes actores: Cristo, Dimas y Gestas, respectivamente el Buen y Mal Ladrón, y otra serie de personajes espectadores: la Virgen, San Juan y la Magdalena, básicamente.

Las directrices que porporcionó Veragua al artista fueron: «el primero (cuadro) el Monte Caluario, y en el a Christo Crucificado en acción de estar espirando en la Cruz y a su lado el Buen Ladron y el Malo y a los pies de Christo Nuestra Señora, san Juan y la Magdalena". Como podemos observar los presupuestos que se le dan al pintor se adaptan a la más rigida ortodoxia contrarreformista.

La Crucifixión constituía un elemento indispensable en la decoración de cualquier iglesia, pues simboliza la garantía de la salvación y la asegura a los propios fieles, convirtiéndose en centro de contemplación e imagen esencial del cristianismo al aunar la redención del hombre y su liberación del pecado original, heredado de Adán, suponiendo el momento culminante de la reconciliación del hombre y Dios, iniciado con la encarnación de Cristo, quien era considerado el «nuevo Adán». Por lo tanto vemos el enlace de la imagen inicial de este programa con la primera del anterior que aludía a la Creación, y cuya segunda escena era precisamente la Encarnación.

La presencia de la Virgen, san Juan y la Magdalena a los pies de la cruz está basada en textos evangélicos como el de san Juan (19: 26-27), donde se narra cómo Cristo encarga a Juan que cuide y proteja a su madre. La Virgen, en ciertas composiciones de pintura flamenca, aparecia desmayándose, expresando de esta manera su dolor, pero esto va a ser censurado por el Concilio de Trento, en el que se afirma que la forma correcta de representarla es ai lado derecho de la cruz de Cristo, firme y enhiesta.

En contraposición a su persona, en el lado izquierdo, se situaria San Juan, representando a los apóstoles que se habian dispersado tras la negación de su maestro y que de nuevo aparecerán reunidos en Pentecostés. Por tanto la cruz está marcando el dualismo de la composición, a un lado la Virgen y al otro San Juan, en la parte inferior del cuadro, y en la superior el Bien y el Mal Ladrón, vuelven a subrayar esta oposición, implicita también en la propia cruz con su madero vertical y el horizontal.

\footnotetext{
${ }^{26}$ Reau, L., Op. cit., II, 2, págs. 499-502.
} 


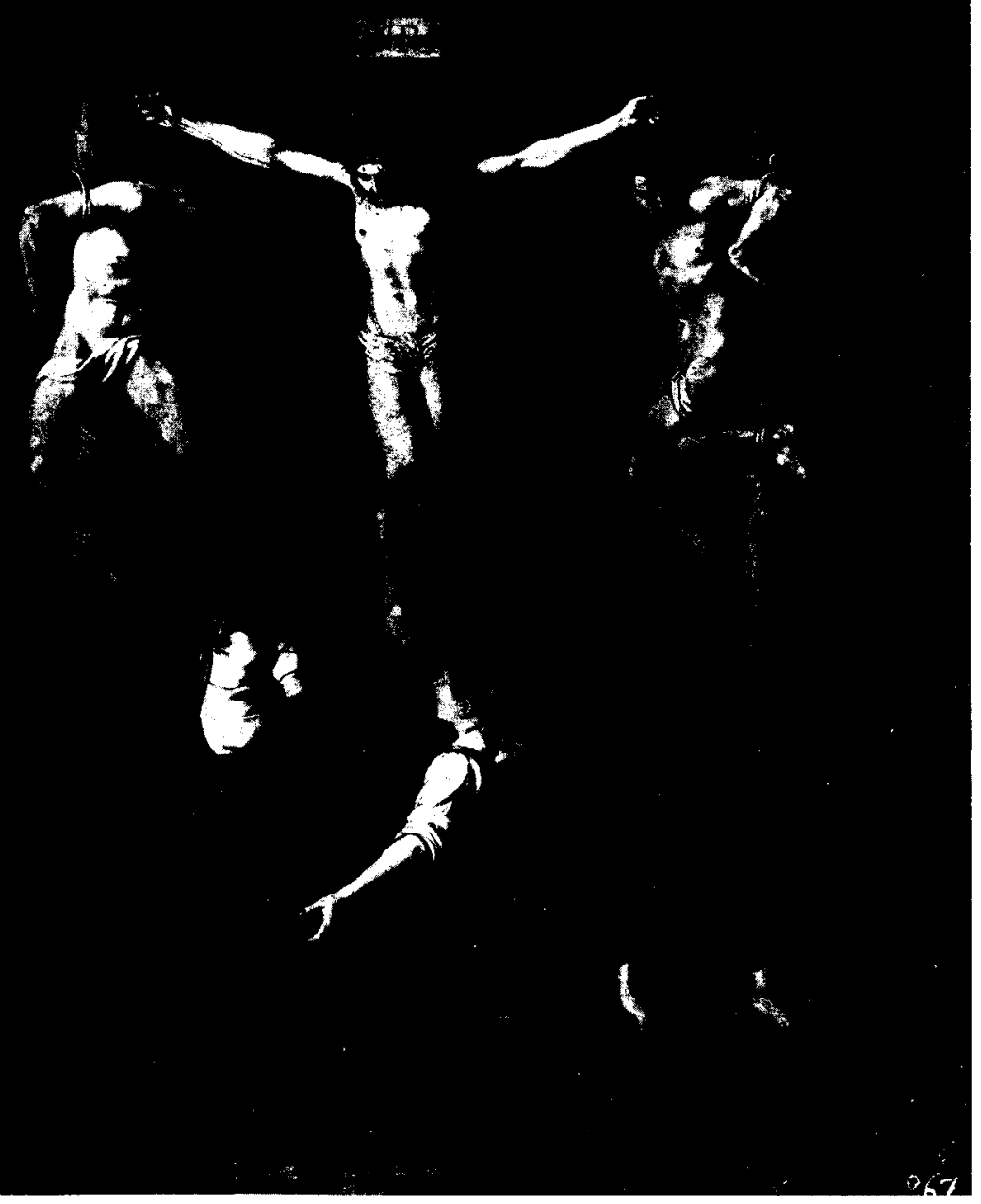

Fig. 11. Pedro de Orrente, "Calvario», Museo del Prado, Madrid.

La otra figura habitual en esta composición es María Magdalena, que, si en vida, arrepentida de sus pecados, ungió los pies de Cristo con perfume, ahora, en su muerte, aparece arrodillada, abrazando la cruz y en otras ocasiones enjugando la sangre de los pies de Cristo con sus cabellos. 
La figura de Cristo, puede aparecer representada o en el momento en que éste ya ha fallecido o bien cuando está expirando y en su cuerpo quedan los últimos hálitos de vida. Precisamente esta última modalidad es la escogida para este programa. Cristo se representa normalmente desnudo, únicamente con el paño de pureza, que exige el decoro hacia su persona, como indicara Pacheco ${ }^{27}$, con la cabeza echada hacia atrás y elevando los ojos al cielo, suspirando por la boca entreabierta. Esta imagen se presenta mucho más conmevedora que la del Cristo ya completamente muerto, pues alude al sufrimiento como via de salvación. Francisco de Sales, tal como recoge Mâle ${ }^{28}$, describe la escena de la siguiente manera: "Sufre exteriormente con un gran silencio; sus ojos, dulces y benignos miran en ocasiones al cielo en el seno de la misericordia del Padre. Su boca sólo se abre para lanzar suspiros de dulzura y de paciencia”.

En otras ocasiones se evidencian en el cuerpo de Cristo las llagas, pues la sangre y agua derramadas evocan los dos sacramentos claves de la Iglesia: el bautismo y la eucaristia.

Artistas que hayan tratado este tema y que al igual que Juan Garcia de Miranda incluyan los dos ladrones, la Virgen, la Magdalena y San Juan, no son tan frecuentes, pero podemos citar a Pedro de Orrente ${ }^{29}$, un anónimo madrileño del siglo XVII ${ }^{30}$ y Juan Martín Cabezalero ${ }^{31}$.

La siguiente escena, representada en el lado opuesto, es la de la Resurrección, que constituye uno de los grandes dogmas de la Iglesia cristiana, al simbolizar la venida de Cristo en forma humana y material, tras la muerte. Se puede establecer un cierto paralelo con las creencias de casi todas las religiones de un dios que renace y resucita, estando por tanto ligado a todos los ciclos regenerativos. En el cristianismo este ciclo "de renovación» alude a la salvación del hombre.

Durante algún tiempo la Iglesia rehusó y evitó la representación de este acontecimiento por no poseer descripciones detalladas para ello en la Escritura y, salvo algunas excepciones, según Hall ${ }^{32}$, no se conocen versiones hasta Giotto.

\footnotetext{
${ }^{27}$ Pacheco, F., Op. cit., págs. 713-734; Interian oe Ayala, J., op. cit., t. I, págs. 431-456.

${ }^{28}$ Male, E., El Barroco, op. cit., pág. 216.

${ }^{29}$ El Calvario, tabla, $153 \times 128 \mathrm{~cm}$, Museo del Prado, Madrid, núm. inv. 1.016

${ }^{30}$ Anónimo madrileño del siglo xVII, El Calvario, $184 \times 165 \mathrm{~cm}$, Museo del Prado, Madrid, núm. inv. 5.148 .

${ }_{31}$ Un lienzo del Monte Calvario en la iglesia de la Venerable Orden Tercera de Madrid.

${ }^{32}$ HaLL, J., op. cit, págs. 269-270.
} 
RESVRRECTIO CHRISTI GLORIOSA, 134 Matth, xxvïg. Marr.xvi, Lur,xxitij. Ioan.xx.

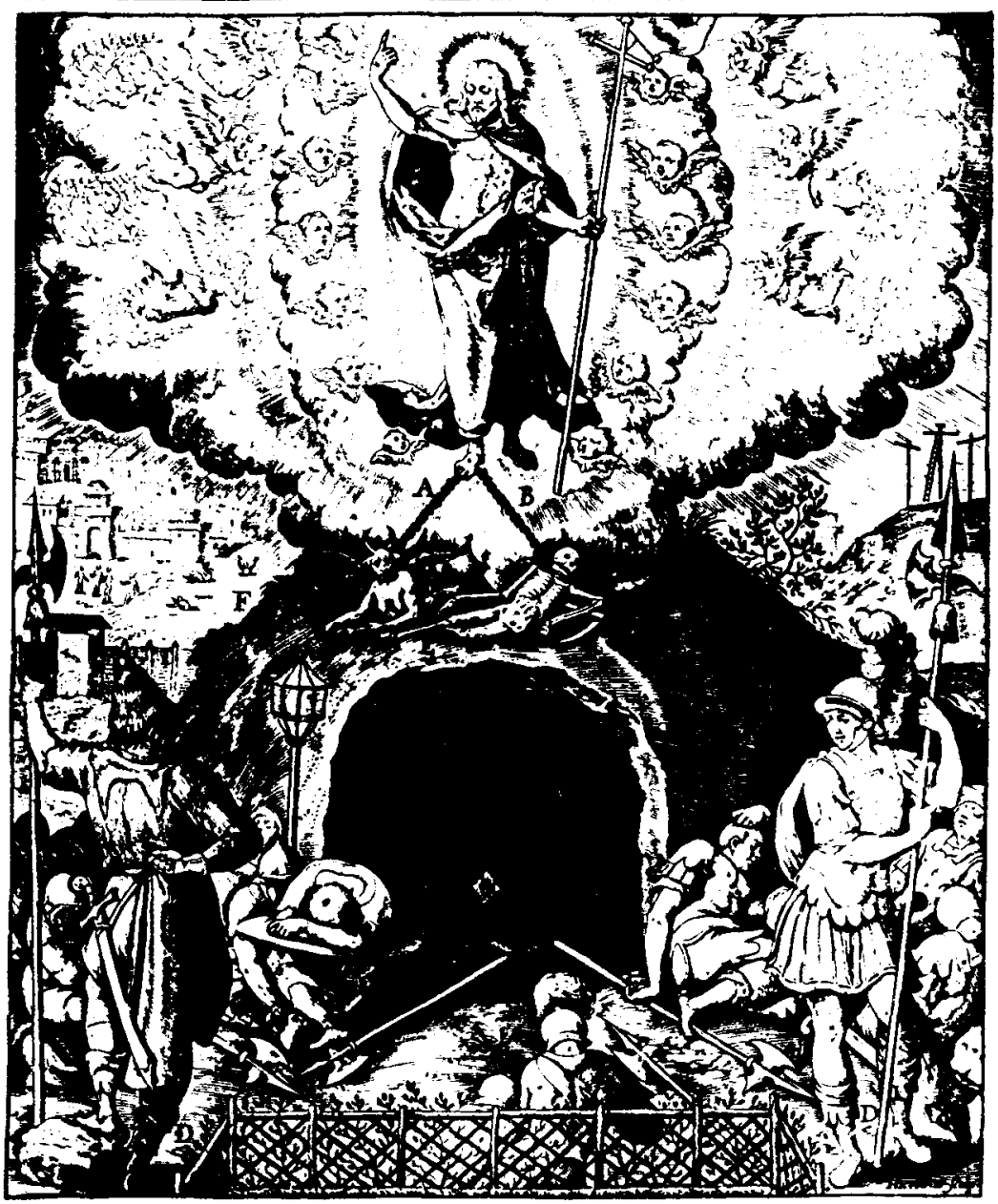

\begin{tabular}{|c|c|}
\hline 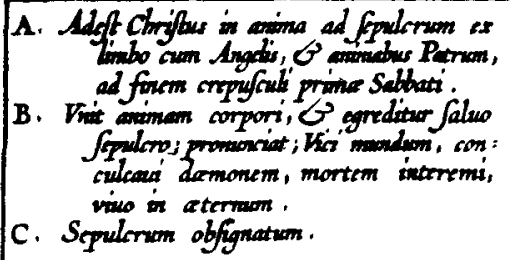 & 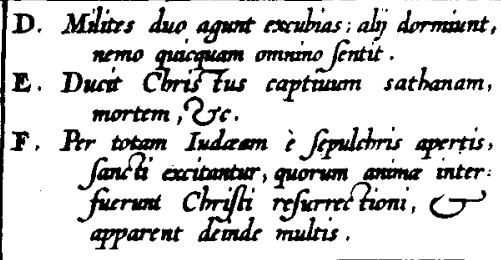 \\
\hline
\end{tabular}

Fig. 12. "Resurrección", grabado reproducido en el libro del Padre Nadal. 
La forma usual de plasmar este prodigio es presentar a Cristo flotando en el aire con una túnica roja, simbolo de que ya ha sufrido la pasión, con un estandarte también rojo, que alude a su victoria sobre la muerte, y el cuerpo resplandeciente y luminoso según lo describe Jerónimo Nadal ${ }^{33}$. También suele ser usual representar la lápida del sepulcro o bien el sepulcro completo, los guardianes romanos que vigilaban, $y$, en otras ocasiones, se incluye el ángel o también a las tres Marias. Se desencadenaron varias polémicas sobre si el sepulcro debia ser representado abierto o cerrado, de las cuales se hace eco, entre otros, Pacheco ${ }^{34}$, y en Trento se vuelve a la fidelidad de las sagradas escrituras, adoptando el modelo descrito por Interián de Ayala ${ }^{35}$, insistiéndose en que el sepulcro ha de estar completamente cerrado y los guardias romanos despiertos y no dormidos como se habia pintado en algunas ocasiones, debiendo figurar despierto al menos uno de ellos.

Por tanto, la Resurrección supone el triunfo de Cristo sobre la muerte, aunque no existen testigos presenciales del milagro.

Representaciones del tema encontramos en Grünewald ${ }^{36}$, Durero ${ }^{37}$, Piero della Francesca ${ }^{38}$, Perugino ${ }^{39}$, El Greco ${ }^{40}$, Maino ${ }^{41}$, y en el libro de Nadal ${ }^{42}$.

Estrechamente unido al tema de la Resurrección se encuentra el Descenso de Cristo al Limbo. No todos los pensadores, críticos, tratadistas ni teólogos coinciden sobre el momento en que aconteció. Para unos, como Pacheco ${ }^{43}$ y los Apócrifos ${ }^{44}$, tendria lugar antes de la Resurrección, pues escriben: "vino su preciosa alma el domingo antes de amanecer con mucha multitud de ángeles al monumento acompañada de las ánimas de los justos que habia sacado del limbo". Para Réau ${ }^{45}$ y Vorágine ${ }^{46}$ tuvo lugar después de la Resurrección. El origen del tema se remonta al arte bizan-

33 Nadal, J., Evangeliae historiae imagines, lám. 134

${ }^{34}$ PaCheCo, F., Op. cit., 648-651. También aportan bibliografia sobre el tema MaLE, E., El Barroco, op. cit., págs. 296-297; Reau, L., op. cit., II, 2, págs. 549-551.

35 Interian de Arala, J., op. cit., 1 . I, págs. 464-474.

${ }^{36}$ Grünewald, retablo de Isenheim.

${ }^{37}$ Xilografia de hacia 1510 y en el retablo de Ober Sanktveit de Viena.

${ }^{38}$ En el Santo Sepulcro del Borgo.

${ }^{39}$ Pinacoteca del Vaticano.

${ }^{40}$ Trinidad, óleo sobre lienzo, $275 \times 127 \mathrm{~cm}$, Museo del Prado, Madrid, núm. inv. 825.

${ }^{41}$ Resurreción, óleo sobre lienzo conservado en el Museo de Villanueva y Geltrú.

42 Nadal, J., Op. cit., lám. 134.

${ }^{43}$ Pachecho, F., Op. cit., pág. 649.

44 Evangelios apócrifos. Madrid 1934, t. II, "Evangelio de Nicodemo», págs. 259 y ss.

45 Reau, L., op. cit., Il, 2, págs. 531-538.

46 Voragine, J.: La légende dorée. Paris, t. I, págs. 278-281. 
tino, propagándose a occidente donde tuvo menor importancia y cobró una nueva significación. En Bizancio y la iglesia griega esta escena reemplaza la resurrección, mientras que en occidente coexisten ambas representaciones y constituyen dos motivos paralelos pero independientes uno de otro.

Los artistas y los actores, contrariamente a los teólogos, no se plantearon nunca la discusión de en qué momento tuvo lugar su descenso al limbo, puesto que plásticamente era más fácil la representación de Cristo en cuerpo que la de dar forma a un alma.

Las fuentes del tema no se encuentran en los evangelios canónicos sino en un sermón de san Agustin y en el evangelio apócrifo de Nicodemo (capitulos XVIII-XXIX) donde se narra con todo detalle "las puertas de bronce se hicieron pedazos... y todos los muertos que estaban detenidos se vieron libres de sus cadenas... y entró el Rey de la gloria" y más adelante prosigue: “el Salvador bendijo a Adán en la frente con la señal de la cruz, y lo mismo hizo con todos los patriarcas y profetas y mártires y antepasados. Y se los llevó y salió del Infierno" ${ }^{47}$. Este texto fue el que se difundió por todo occidente a través del Speculum de Vicente Beauvais y la Leyenda dorada de Vorágine.

El origen del tema parece remontarse al mundo clásico, a las figuras de Orfeo y Hércules.

Esta escena se representa, con ligerísimas variantes, siempre de la misma manera: Cristo con apariencia humana, llega al limbo, donde libera a Adán y a los justos y patriarcas de la antigua ley.

Otro aspecto debatido es el lugar al que Cristo desciende, que, según distintas interpretaciones, seria el limbo, donde permanecian los justos no bautizados.

En el documento de Guadalupe se indica al pintor que «representará a Christo descendiendo a los Infiernos". Al no señalar nada más suponemos que en su iconografia y composición Miranda se ajustó a lo habitual y tradicional en estas escenas.

Este tema fue recreado por Sebastiano del Piombo ${ }^{48}$, Tintoretto ${ }^{49}$, Angelo Bronzino ${ }^{50}$, Bartolomé Bermejo ${ }^{51}$, Alonso Cano ${ }^{52}$, Ribalta ${ }^{53}$, Carducho ${ }^{54}$, etc.

47 "Evangelio de Nicodemo", Evangelios apócrifos, op. cit., t. II, págs. 267-268.

${ }^{48}$ Óleo sobre lienzo, $226 \times 114 \mathrm{~cm}$, Museo del Prado, Madrid, núm. inv. 7.595

${ }^{49}$ Lienzo conservado en San Casiano de Venecia. 
Un programa iconológico perdido, recuperado. Pinturas de la ...

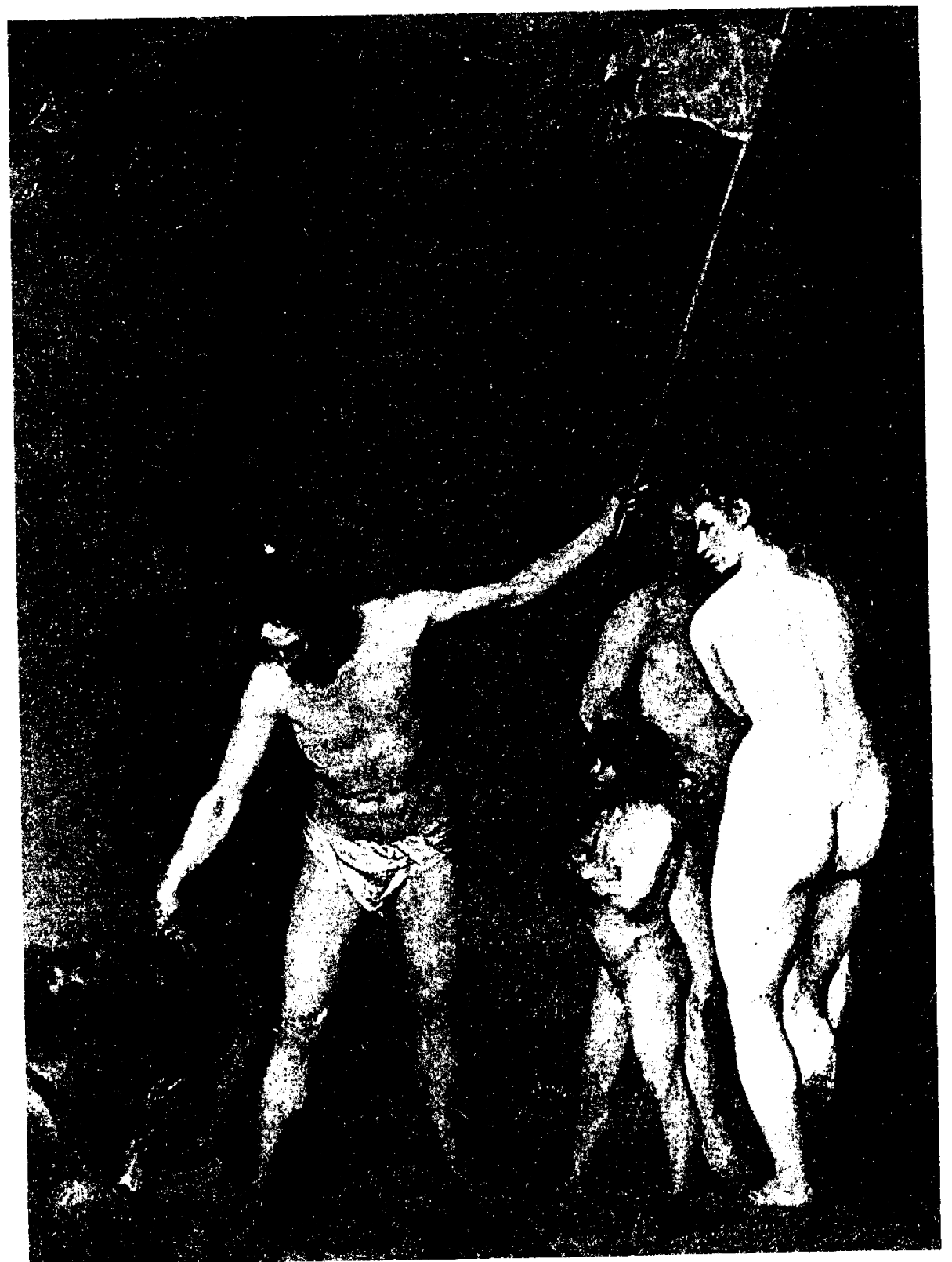

Fig. 13. Alonso Cano, "Descenso al limbo", Los Angeles County Museum, Los Ángeles. 
El siguiente altar a comentar estaba decorado por el lienzo de la Ascensión. Dicho acontecimiento sucedió cuarenta días después de la muerte de Cristo y supone la última aparición de Cristo a los apóstoles en el monte de los Olivos.

Las fuentes del misterio se encuentran en el evangelio de san Lucas $(24,50-53)$ y en los Hechos de los Apóstoles $(1,9-12)$ donde se narra del siguiente modo: "Dicho esto, lo vieron subir, hasta que una nube lo ocultó a sus ojos. Mientras miraban fijos al cielo viéndole irse, se les presentaron dos hombres vestidos de blanco que les dijeron: «Galileos ¿Qué haceis plantados mirando al cielo? El mismo Jesús que se han llevado de aquí al cielo volverá como lo habeis visto marcharse». También aparece recogido en los evangelios apócrifos, especialmente en el de Nicodemo.

A nuestro pintor se le da la orden de plasmar una Ascensión. En ocasiones los artistas asimilaron a la Ascensión algunos detalles de la Resurrección. La elevación es realizada por el propio Cristo sin la ayuda de ángeles ni por intervención de la mano de Dios Padre, lo que la distingue de otras ascensiones de Enoc, Elias, etc. -considerados prefiguras de Cristo- que son auxiliados por Dios ${ }^{55}$. Su cuerpo debió aparecer, de acuerdo con las indicaciones de Pacheco, refulgente pero con las llagas de la pasión. Y, como comenta Vorágine, éstas deben mantenerlas hasta el día del juicio para confirmación y recuerdo de su Resurrección y poder mostrarlas al Padre al que suplicará en favor de los hombres. Detalles con los que podemos confirmar las interferencias entre la iconografia de las dos escenas antes anotadas.

Se le representa respondiendo al texto de los Apóstoles: con todo el cuerpo entero, apoyado en una nube y rodeado de ángeles que le alaban; en la tierra quedan los apóstoles contemplándolo con su mirada trascendida y atónita. El hecho en sí da lugar a una composición artística bastante frecuente en pintura desde el Renacimiento, la de dividir el lienzo en dos partes, correspondiendo la superior al cielo y la inferior a la tierra; recurso muy empleado desde Rafael, El Greco, etc.

${ }^{49}$ Lienzo conservado en San Casiano de Venecia.

${ }^{50}$ Cuadros conservados en la Galería de los Uffizi y en Santa Croce.

${ }^{51}$ Obra conservada en el Museo de Arte de Cataluña. Barcelona.

${ }^{52}$ Descendimiento al limbo. Museo de los Ángeles.

${ }^{53}$ Lienzo conservado en la iglesia de San Martín de Segorbe.

${ }^{54}$ Descenso al limbo, en Santo Domingo de Bemfé, Lisboa.

${ }^{55}$ Voragine, J., op. cit., t. I, págs. 358-367; Pacheco, F., op. cit., págs. 648-651; INTERIAN de Ayala, J., op. cit., t. I., págs. 474-476; Reau, L., op. cit., II, 2, págs. 582-591; Hall, J., op. cit., págs. 50-51. 
Un programa iconológico perdido, recuperado. Pinturas de la ...

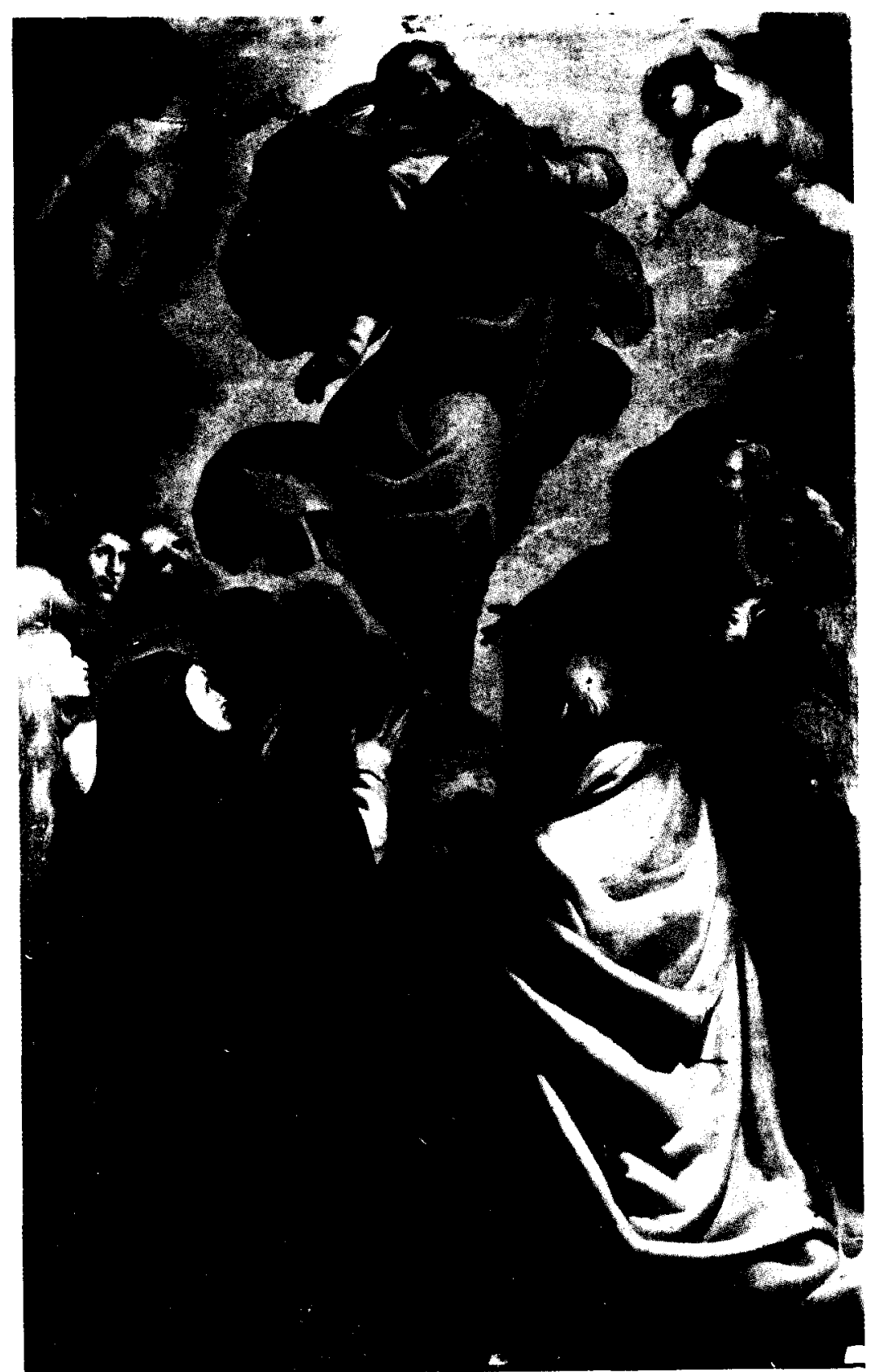

Fig. 14. Lanchares, "Ascensión», Museo del Prado, Madrid. 
Ejemplos de esta creación tan próxima a la de la Transfiguración y con la que a veces se confunde, dentro del arte español, podemos mencionar la de Antonio Lanchares, que se custodia en el Museo del Prado ${ }^{56}$, y el anónimo español del siglo XVII ${ }^{57}$ recientemente expuesto en el Museo de Ciudad Real. Entre las versiones italianas contamos con la de Giotto en los frescos de la Arena, en Padua; y, un siglo después, las bellísimas de Fra Angelico (Academia de Florencia), que mantiene la tradición de Cristo desaparecido entre las nubes, y la de Mantegna (en los Uffizi, Florencia). En el siglo XVI, Correggio nos recrea con su plasmación en la cúpula de la iglesia de san Juan Evangelista, en Parma.

La fuente escrita motivo de inspiración para el tema precedente de la Ascensión de Cristo al cielo se utiliza también para la creación de otra representación: "la glorificación de Cristo", o dicho de otro modo, "Cristo en la Gloria sentado a la diestra de Dios Padre». Este texto también se encuentra recogido en la escritura del contrato por el cual es realizado el lienzo que estudiamos.

Cristo subió al cielo, según la expresión de San Pablo en su Epistola a los Efesios (IV): «El que descendió, es el mismo que asciende al cielo a fin de llenar todas las cosas».

En el Antiguo y Nuevo Testamento, el cielo, si bien se emplea en diversos sentidos, indica, especialmente el lugar de donde vino Cristo y adonde volvió, que es el de los elegidos. En el Deuteronomio $(3,24$, etc.) cielo equivale a firmamento. En los Salmos $(90,135$, etc.) se habla del cielo como del lugar o del estado de los justos que gozan de Dios después de la muerte. El cielo significa ya la visión o la presencia de la gloria de Dios, el Paraiso, la vida angélica y verdadera, el eterno descanso.

Es evidente que Cristo subió hasta el cielo sobrenatural ${ }^{58}$, es decir, hasta el trono de Dios, según estas palabras de san Marcos (XVI, 19): "Y el Señor Jesús después de haberles hablado, subió al cielo, donde está sentado a la derecha de Dios". Esta expresión de la derecha de Dios indica su igualdad en todo con él. De igual modo lo expresa el Salmista $(110,1)$ : «Dijo el Señor a mi Señor, siéntate a mi derecha»... Expresiones todas que explicitan la glorificación que recibe tras su ascensión.

Éste seria el texto o fuente de la plasmación de Juan Garcia de Miranda, al que, como es habitual, solia ajustarse con precisión si bien igualmente hemos de subrayar la singularidad de esta representación.

\footnotetext{
${ }^{56}$ Oleo sobre lienzo, $162 \times 100 \mathrm{~cm}$, Museo del Prado, Madrid, núm. inv. 6.781.

${ }^{57}$ Óleo sobre lienzo, $175 \times 122 \mathrm{~cm}$, Museo del Prado, Madrid, núm. inv. 5.609.

s8 Voragine, J., op. cit., t. I, págs. 365-367; Champeaux, Gérard de y Sterckx, Sébastien, op. cit. Madrid 1984, págs. 17-32, 89, 91, 203 y 299.
} 


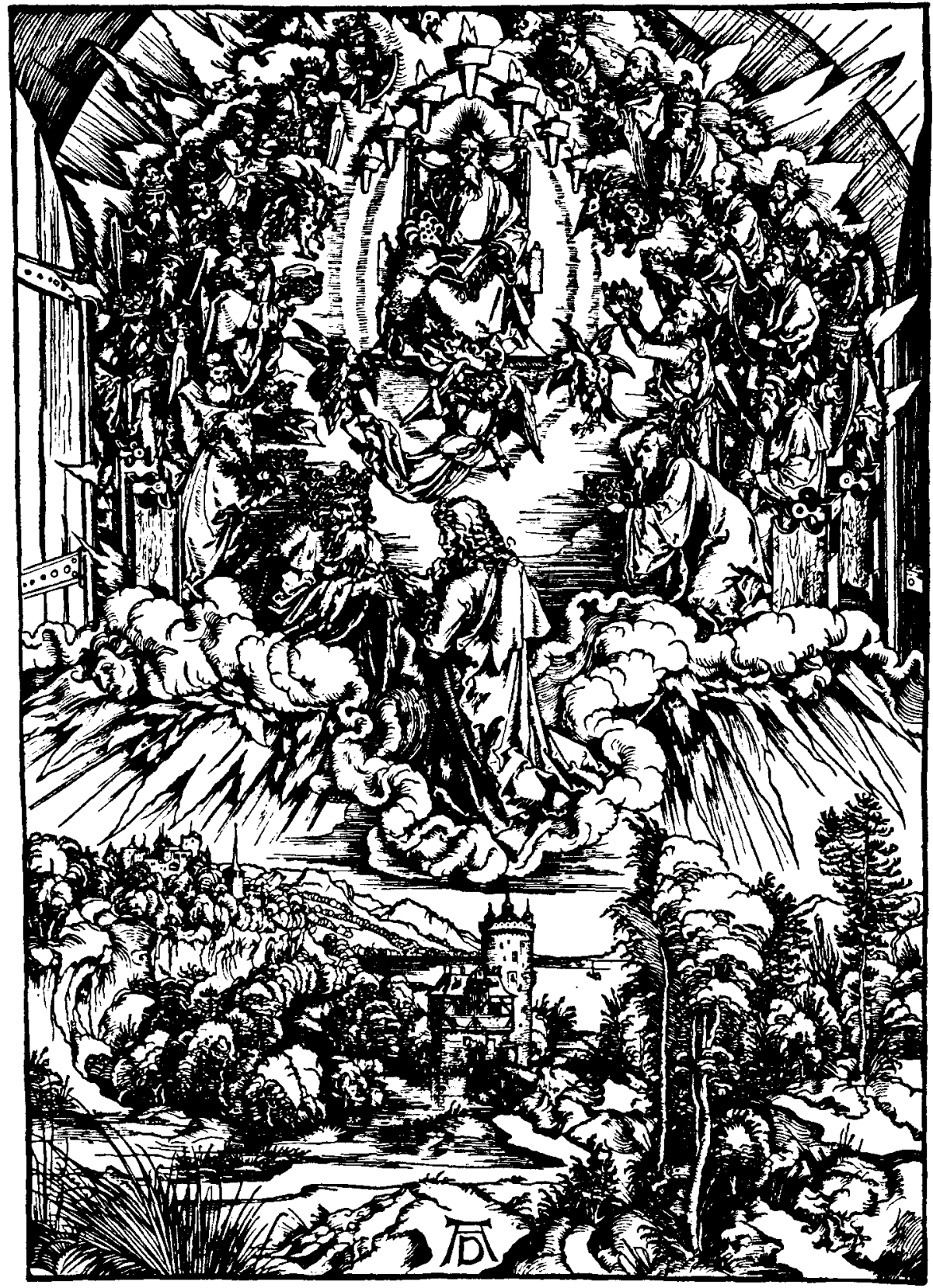

Fig. 15. Durero, "Cristo en la gloria», grabado de la serie del Apocalipsis. 
Plásticamente no gozó de excesiva difusión el tema, sino más bien se le representó implícito en otras escenas gloriosas como la "Misión de los Apóstoles y Pentecostés" (Basilica de la Magdalena de Vézelay), la "Visión Apocalíptica» (san Pedro de Moissac) y "Cristo en la gloria» de Saint Gilles du Gard. Otra versión posterior, que mantiene esta misma iconografia, son las "visiones de todos los santos en la gloria", como la pintada por Carducho (Santo Domingo de Bemfica, Lisboa).

El Juicio Final, habitualmente, dentro de la estética románica, solía decorar el tímpano de la fachada principal, la occidental, de las iglesias de peregrinación. El fruto de estas reminiscencias medievales justificaria la presencia de esta escena en los pies de nuestra iglesia, pues en el documento se explicita que inmediato a la puerta de la Iglesia se representará el «Juicio universal y final». Esta elección no es gratuita pues se ofrece como tema de meditación al fiel que entra, el cual precisamente está alli para buscar su salvación. Por otra parte, también es lógica su presencia pues en esta imagen se ofrece un compendio de toda la historia y proceso de salvación de la humanidad, estando presentes los personajes del Antiguo y Nuevo Testamento, ángeles, santos, etc. y representada toda la humanidad, por tanto es el gran compendio final, que supone el inicio de una nueva vida tanto para los elegidos como para los condenados ${ }^{59}$.

Cristo había resucitado pero los hombres seguian condenados y era necesario que los justos fuesen recompensados y los impios condenados, siendo imprescindible el ejercicio de la justicia triunfante aspiración generalizada a lo largo del tiempo. Entre las fuentes que nos narran o profetizan el episodio del Juicio Final se encuentran en el Antiguo Testamento, el libro de Daniel $(7,13 ; 12,4)$, libro de Job $(19,25 ; 41,3-25)$, en el Nuevo Testamento destaca sobre todo san Mateo (24, 30-32; 25, 31-46), y por último podríamos añadir los apocalipsis griegos y el evangelio apócrifo cátaro del pseudo Juan (5, págs. 376-378).

Mateo nos narra la escena del siguiente modo "Cuando este Hombre venga con su esplendor acompañado de todos sus ángeles, se sentará en su trono real y reunirán ante él todas las naciones. Él separará a unos de otros, como un pastor separa a las ovejas y a las cabras, y pondrá a las ovejas a su derecha y a las cabras a su izquierda», más adelante prosigue diciendo que serán juzgados por sus obras para concluir aseverando que los condenados "irán al castigo eterno y los justos a la vida eterna".

El protagonista en estas representaciones es Cristo Juez sentado en majestad o entronizado sobre una nube, y a partir del siglo xIII se insiste

${ }^{59}$ Champeaux, G. De y Sterckx, S., op. cit., págs. 507-511. 
Un programa iconológico perdido, recuperado. Pinturas de la ...

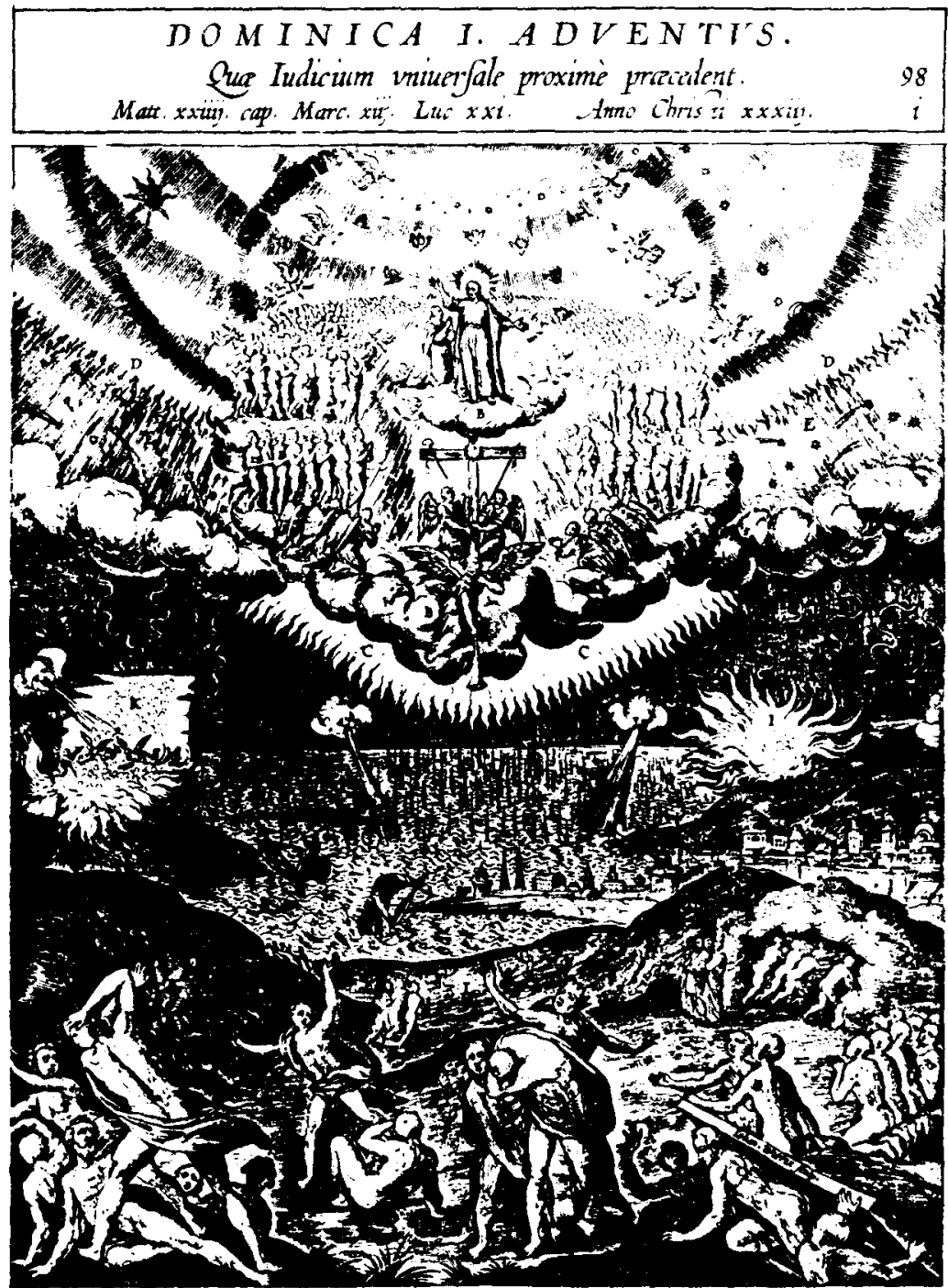

A. Signa in calo, sole, Lwe, oj fellis, wi.

B. Crrition ad indriom venientem prece: dunt crux, arteraque infgria pasfionis, $\sigma$ Arthangedes con twha.

C. Pracedit ignss orbem purgaturus.

D. Elementwom ignis mundo quafi ninitomer.

E. Aleris fogrrma regio.

F. Acris media regu.

G. Arris infime regio. Es in his omnitus torribilia Jigna.

H. Confufio maris, os flus turum, Gic.

I. Os unferni epertum.

K. Exiam purgasorÿ.

L. In terra nTwem onrrion horribitis facies, quar othi terrorsm incutict whementifimen Alise fegne non poruat oxpere inago.

Fig. 16. "Juicio Final", grabado del libro del Padre Nadal. 
en la idea de Cristo Redentor, por lo que además de juzgar, muestra las llagas de la Pasión, que justifican la salvación de los hombres. En otras ocasiones en vez de enseñar las llagas se le representa rodeado de ángeles que portan los instrumentos de la pasión (columna, clavos, esponja, etcétera). Junto a Cristo suelen estar casi siempre representados la Virgen, a la derecha, y san Juan, a la izquierda, constituyendo la déesis. La primera aparece como intermediaria a favor de los hombres y San Juan como predecesor de Cristo. Esta escena normalmente ocupa la parte alta de las composiciones dando lugar a un enorme despliegue de nubes y ángeles, no faltando los ángeles con trompetas anunciadores del comienzo del Juicio Final.

Otros testigos de Cristo a la hora de celebrar el Juicio son los veinticuatro ancianos del apocalipsis y los apóstoles, todos ellos situados en los lugares próximos a Cristo y normalmente en el lado derecho.

Junto a Cristo la otra gran protagonista es la Humanidad, que va a ser juzgada, tanto los vivos como los muertos, quienes han de dar cuenta ante este Juez Supremo. En las representaciones medievales este acontecimiento daba motivo para la inclusión de un tema cuya tradición se remonta a otras culturas orientales, como la egipcia, relativa al pesaje de las almas y para ello se efigiaba a san Miguel con la balanza pesando almas y el demonio siempre atento intentando hacer trampa.

La celebración del Juicio comporta como consecuencia que los elegidos acompañados por los ángeles se dirijan, normalmente con movimientos ascendentes, hacia la gloria, donde ya suelen estar esperándolos los santos y otros personajes justos del Antiguo Testamento como Moisés, David, etc. y por supuesto Abraham, pues se identifica al paraiso con una vuelta al seno de Abraham. En un lugar bastante visible suele estar san Pedro con las llaves de la «gloria», siendo el encargado de la apertura de esas supuestas puertas paradisiacas al igual que lo había sido en la Tierra, como predecesor de todos los Papas y encargado de los destinos de la Iglesia. La figuración del Paraíso da pie a otros artistas para la introducción de visiones de la Jerusalén celestial.

Por otra parte, los condenados, castigados a las penas del Infierno, son recibidos por Satanás, representado normalmente con el aspecto de una figura grotesca y monstruosa con cuernos, que recuerda el aspecto de los faunos clásicos. Él es quien se hace cargo de todos los condenados, que son conducidos al infierno, concebido durante mucho tiempo como la boca de un monstruo que despedia humo por las fosas nasales y dientes muy afilados. La figuración del infierno da pie a la libertad imaginativa del artista que podia representar a los hombres condenados a 
distintas penas o castigos, aguzados constantemente por toda una serie de seres demoniacos.

Durante muchísimo tiempo solamente se representaba el cielo y el infierno, pero a partir de la Contrarreforma se incluye un tercer espacio, el Purgatorio, que se diferencia del Infierno en que alli hay condenados, pero en vez de estar castigados para toda la eternidad, están sólo momentáneamente hasta que rediman sus pecados y puedan pasar a formar parte de los elegidos. La Contrarreforma centró todo su afán en defender la existencia del Purgatorio, frente a los protestantes que ponian en duda su veracidad, pues no se fundaba en textos evangélicos sino en el Libro de los Macabeos. Los reformistas estimaban que precisamente la defensa del Purgatorio y toda la subsecuente salvación de las almas es la que había creado todo el sistema de las indulgencias, que precisamente ellos atacaban. De ahi que la Iglesia Católica insista en su representación combatiendo de forma activa con imágenes a los disidentes.

Existieron varias polémicas sobre cómo había que representar a los hombres que resucitaban. Para unos la resurrección tenía lugar simultáneamente para todos al mismo tiempo, pero otros opinaban que ésta tenía lugar en momentos sucesivos y progresivamente iban abriéndose las lápidas de los sepulcros. También se discutía si los resucitados deberían tener el mismo sexo o edad; finalmente, al menos en lo que a las figuraciones plásticas hace referencia, triunfa el criterio de representarlos de la edad de treinta o treinta y tres años, o sea, la misma de Cristo cuando murió. Por tanto no aparecerán nunca ni niños ni ancianos, y se adopta la fórmula de que sean figuras sexuadas, distinguiéndose los hombres de las mujeres. Precisamente el Juicio Final, era una de las pocas escenas religiosas que permitía la inclusión de desnudos por parte de los artistas, de ahí que diversos tratadistas de la Contrarreforma insistiesen en la corrección y decencia a la hora de pintar este acontecimiento, recomendaciones que arrecian sobre todo después de haber pintado Miguel Ángel su famoso Juicio, donde los protagonistas son los cuerpos humanos desnudos. Lo frecuente a partir de estos momentos suele ser representar a los elegidos vestidos y a los condenados desnudos, como símbolo de humillación ${ }^{60}$.

Este tema ha sido abundantemente representado en escultura, pintura, miniatura y grabado, entre los que podemos citar Chartres, Autun,

60 Reau, L., Op. cit., II, 2, págs. 727-757; MaLe, E., L'art religieux de la fin du Moyen Age. Paris 1969, págs. 449-479; MALE, E., El Barroco, arte religioso del siglo xvi, op. cit., pág. 203; "Evangetio cátaro del pseudo-Juan", Los evangelios apócrifos, op. cit., t. II, pág. 376; PACHEco, F., op. cit., págs. 322-341; InTERIAN de Ayala, J., op. cit., t. I, págs. 476-482. 
Giotto ${ }^{61}$, Fra Angélico ${ }^{62}$, Lucas Signorelli ${ }^{63}$, Miguel Ángel ${ }^{64}$, Rubens ${ }^{65}$, Juan Correa del Vivar ${ }^{66}$, Luis de Vargas ${ }^{67}$, Murillo ${ }^{68}$, Teniers ${ }^{69}$, etc.

El programa contrarreformista se completa con las escenas pintadas en las dos capillas del presbiterio, una de ellas se decora con temas correspondientes al mundo glorioso: los «ángeles", el "purgatorio», a medio camino entre el infierno y el paraíso donde, como habiamos dicho anteriormente, se encuentran las almas en un estadio intermedio antes de alcanzar la gloria, y finalmente Todos los Santos. Por su parte, en la otra capilla se sitúan imágenes de los protectores de los cristianos que les ayudan en su camino hacia la salvación, habiéndose elegido en esta ocasión, por motivos que analizaremos más adelante, la Virgen de Belén, el Santo Ángel de la Guarda y san Pedro.

El lienzo de la Virgen de Belén, aunque no lo conservamos, sí poseemos el testimonio del Duque de Veragua que desea una “Nuestra Señora de Belén en la forma en que se halla pintada en su capilla del Hospital de San Juan de Dios de esta Corte". Esta obra fue realizada por Francisco Camilo en 1662, gozando de tan gran popularidad que el artista realizó diversas copias.

La Virgen de Belén es una Virgen con el Niño, que también podría llamarse Virgen de ternura porque la relación entre ambos tiene siempre este carácter, cualidad que en el caso de la de Camilo era evidente dado sus expresiones dulces, sentimentales y devotas. Hablan de ella Madoz ${ }^{70}$, Ceán ${ }^{71}$, Palomino ${ }^{72}$, Ponz ${ }^{73}$, Tormo ${ }^{74}$, Angulo ${ }^{75}$, hasta el extremo de encomiarla, diciendo que aunque pequeña en la cantidad es sin limites en la perfección. Este lienzo se veneraba en la capilla particular de la iglesia de San Juan de Dios en Madrid, convento que llaman de Antón Martín, su fundador.

${ }^{61}$ Capilla de la Arena de Padua.

${ }^{62}$ Academia de Bellas Artes de Florencia.

${ }^{63}$ Capilla de Orvieto.

${ }^{64}$ Capilla Sixtina en San Pedro del Vaticano.

${ }^{65}$ Gran y Pequeño Juicio. Pinacoteca de Munich.

${ }^{66}$ Oleo sobre lienzo, $136 \times 110 \mathrm{~cm}$, Museo del Prado, Madrid, núm. inv. 2.479 .

${ }^{67}$ Lienzo propiedad de la Fundación Rodríguez Acosta.

${ }^{68}$ Hospital de la Caridad de Sevilla.

${ }^{69}$ Museo del Louvre, Paris.

${ }^{70}$ Madoz, P., Madrid, 1848, t. X, págs. 361-362.

7 Cean Bermujoez, Juan Agustin, op. cit., t. I, pág. 198.

${ }^{72}$ Palomino, A. A., op. cit., págs. 973.

${ }^{73}$ Ponz, A., op. cit., t. V, págs. 57-59.

74 Tormo, Elias, Iglesias del antiguo Madrid. Madrid 1972, págs. 217-219.

75 Angulo lñıguez, Diego, "Francisco Camilo», Archivo Español de Arte. Madrid 1959, pág 95. 
Un programa iconológico perdido, recuperado. Pinturas de la ...

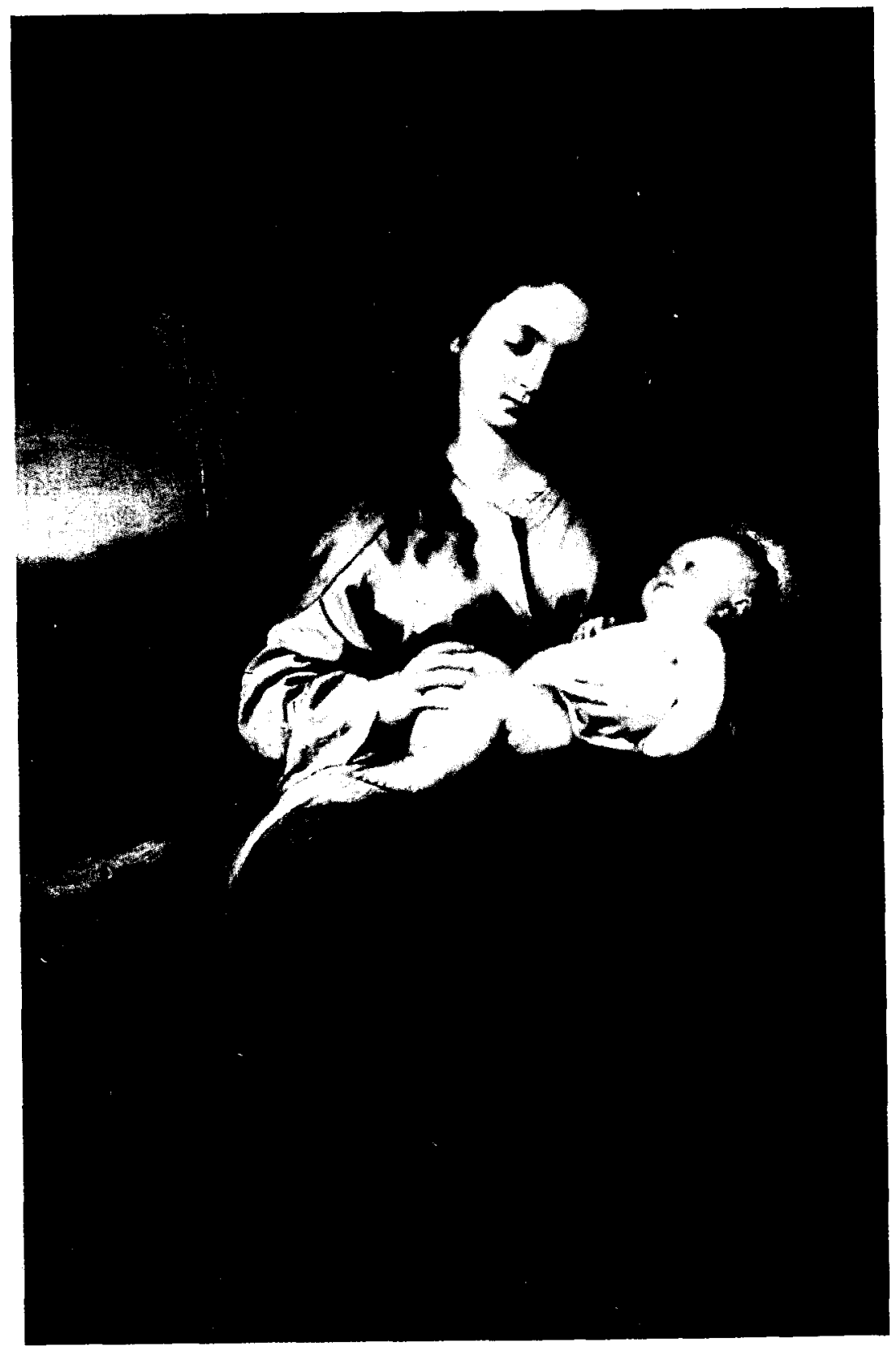

Fig. 17. Alonso Cano, "Virgen de Belén", Museo del Prado, Madrid. 
La elección de este tema mariano podriamos pensar que radica en la veneración jerónima por esta Virgen, debido a la larga permanencia de San Jerónimo en Belén, donde murió. Otra causa podria ser la devoción de Veragua hacia dicha advocación o pudo influir también que la capilla del convento de Antón Martín fuese escenario de sus dádivas y generosidad.

La Virgen de Belén es la protagonista de varias obras artísticas de Alonso Cano ${ }^{76}$, Maino ${ }^{77}$, Francisco de Pacheco ${ }^{78}$, Clemente de Torres ${ }^{79}$.

El segundo de los protectores ha de ser «el Santo Ángel de la Guarda teniendo a un niño de la mano significando el alma a quien enseña el camino del Zielo". Esta es la forma más significativa y tradicional de la representación del ángel de la guarda, tema nacido en el arte y en el culto desde el siglo xvI, siendo su principal defensor el obispo de Rodez. Esta imagen agradable, que custodiaria vigilantemente desde el nacimiento hasta la muerte, fue muy bien acogida en los ámbitos artísticos y devocionales. Su representación se reduce a la figura de un espiritu celeste encarnado en un joven adolescente atrativo y un niño, rara vez adolescente, a quien guia y protege. Esta escena generalmente apacible y dulce, cobra un cierto tinte dramático cuando el ángel ha de defender a su protegido del demonio. En ocasiones se asocia el arcángel Rafael y Tobias con el Angel de la Guarda y el niño ${ }^{80}$.

Entre las representaciones abundantisimas figuran las de Carracci ${ }^{81}$, Murillo ${ }^{82}$, Giovanni Baratta ${ }^{83}$, Carlo Bonone ${ }^{84}$, José Risueño ${ }^{85}$, Domenichino ${ }^{86}$, Paul Bril ${ }^{87}$, Pietro da Cortona ${ }^{88}$.

El tercer y último lienzo corresponde a «San Pedro penitente y lloroso en su ceguera". Este tema sirvió de argumento para los católicos a favor del sacramento de la penitencia contra las tesis protestantes. Bellarmin, inspirándose en san Ambrosio, afirmaba que las lágrimas de san Pedro,

\footnotetext{
${ }^{76}$ Catedral de Sevilla y escultura de la catedral de Granada.

${ }_{77}$ Mercedarias de Fuentes de Andalucia.

${ }^{18}$ Lienzo de la catedral de Granada.

${ }^{79}$ Mercedarias Calzadas de Sevilla.

${ }^{30}$ Reau, L, op. cit., II, 1, págs. 33 y 53; Male, E., El Barroco... op. cit., pág. 263; Revilla, F., op. cit., págs. 31-32; HaLl, J., op. cit., pág. 36.

${ }^{81}$ B. N. Paris. Gabinete de estampas BD 23.

${ }^{82}$ Catedral de Sevilla.

83 Iglesia del Espíritu Santo de Florencia.

${ }^{24}$ Pinacoteca de Ferrara.

${ }^{85}$ Monasterio de San Jerónimo de Granada y colección particular granadina.

${ }^{86}$ Galeria Nacional de Capodimonte, Nápoles.

${ }^{87}$ Grabado de Perelle, B. N. Paris, Estampas C. C. 23, fol. 33.

${ }^{88}$ Iglesia de San Biagio de Roma.
} 
Un programa iconológico perdido, recuperado. Pinturas de la ...

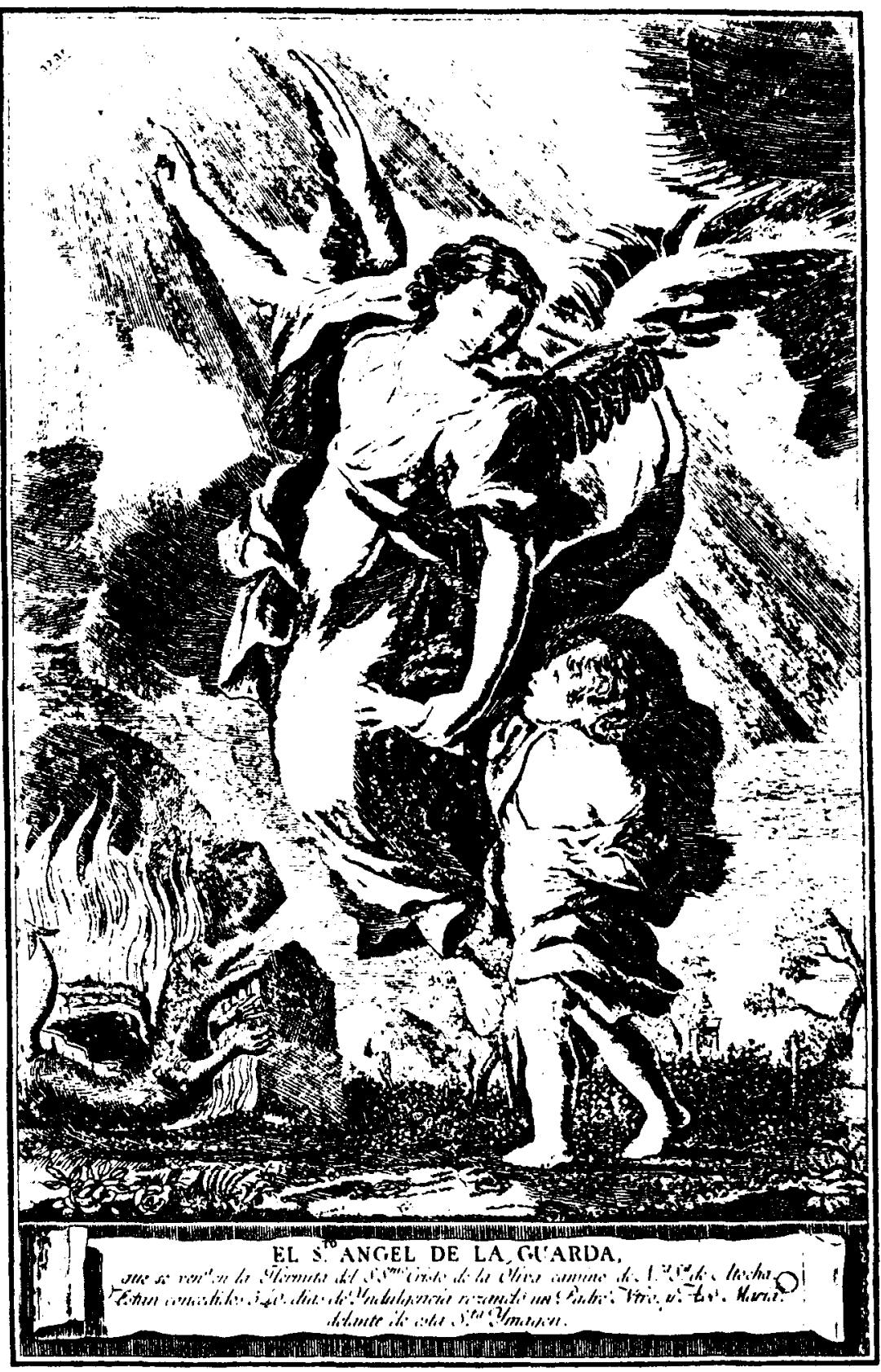

Fig. 18. Andrés de la Muela, "Angel de la Guarda", Museo Municipal de Madrid, grabados, núm. 14.177 . 
desesperado por haber negado tres veces a su maestro eran una imagen de la confesión ${ }^{8}$. Para los cristianos se convirtió en un tema de meditación, que pasó a la literatura y, a partir del siglo xvi, al arte.

El tema tenia en aquella época una notable significación dogmática. Parece evidente que la figura simbólica de san Pedro arrepintiéndose fue propuesta inicialmente por la Iglesia a los pintores y con ello les complacía enormemente pues podian representar actitudes patéticas, manos crispadas, ojos levantados al cielo, lágrimas y gestos usuales en la época ${ }^{90}$. A las razones aducidas se sumaría la predilección del comitente, don Pedro Nuño, por la figura de san Pedro, su Santo patrono.

Un grabado de Anibal Carracci ${ }^{91}$ y varios cuadros de El Greco ${ }^{92}$ constituyen algunas de las primeras representaciones del tema, a partir del XVII alcanzó un auge sorprendente, con obras de Reni ${ }^{93}$, Lanfranco ${ }^{94}$, Domenichino ${ }^{95}$, Guercino ${ }^{96}$, Velázquez ${ }^{97}$, Ribera ${ }^{98}$, Nardi ${ }^{99}$, Lucas Jordán ${ }^{100}$, etc.

Las representaciones del lado de la epistola se inician, como reza en el documento, con «todos los ángeles en degradación proporcionada a su multitud y de los que vengan a rematarse en la fachada exterior del quadro con la altura entera se distinguirán los ángeles principales figurando en su deuido orden y al pie de cada uno de ellos se pintarán las letras de sus respectivos nombres". Durante el siglo XVI se difunde la devoción a los ángeles y en el siglo siguiente, el XVII, se consagra definitivamente el culto por parte del Papa y se les dedican capillas.

Como su nombre indica los ángeles tienen por misión actuar de mensajeros entre Dios y los hombres, su origen se remonta al mundo original. Las fuentes del tema se encuentran en el libro del Génesis $(18,2 ; 19,1)$ y en Tobias.

\footnotetext{
${ }^{89}$ Male, E., El Barroco..., op. cit., págs. 88-89.

${ }^{\circ}$ INTERIAN de Ayala, J., op. cit,, t. Il, págs. 445-446; Reau, L., op. cit., III, 3, págs. 10761087; Voragine, J., op. cit., T. I., págs. 209-214; Ferrando Rolg, J., op. cit., pág. 218; Hall, J., op. cit., págs. $250-251$.

${ }_{91}$ Grabado por Domenico Conti, Roma, Est. 41-H-11.

${ }_{92}$ Oleo sobre lienzo, $102 \times 84 \mathrm{~cm}$, Hospital de San Juan Bautista de Toledo.

${ }^{93}$ Museo de Ermitage.

${ }^{94}$ Gradado por Levitain, B. N. París, Estampas, BD, 9A.

${ }_{95}$ Oleo sobre lienzo, $28 \times 21 \mathrm{~cm}$, Museo del Prado, Madrid, núm. inv. 133

${ }^{96}$ B. N. Paris, Estampas, BD. 34.

${ }^{97}$ Óleo sobre lienzo, colección Beruete, Madrid.

${ }^{98}$ Tiene varias representaciones, entre las que se encuentran las del Ermitage, ermita de la Soledad de Toledo y Museo de Lyon.

${ }^{99}$ Archivo Mas, Barcelona.

100 Oleo sobre lienzo, $68 \times 70 \mathrm{~cm}$, Museo del Prado, Madrid, núm. inv. 173.
} 
Un programa iconológico perdido, recuperado. Pinturas de la ...

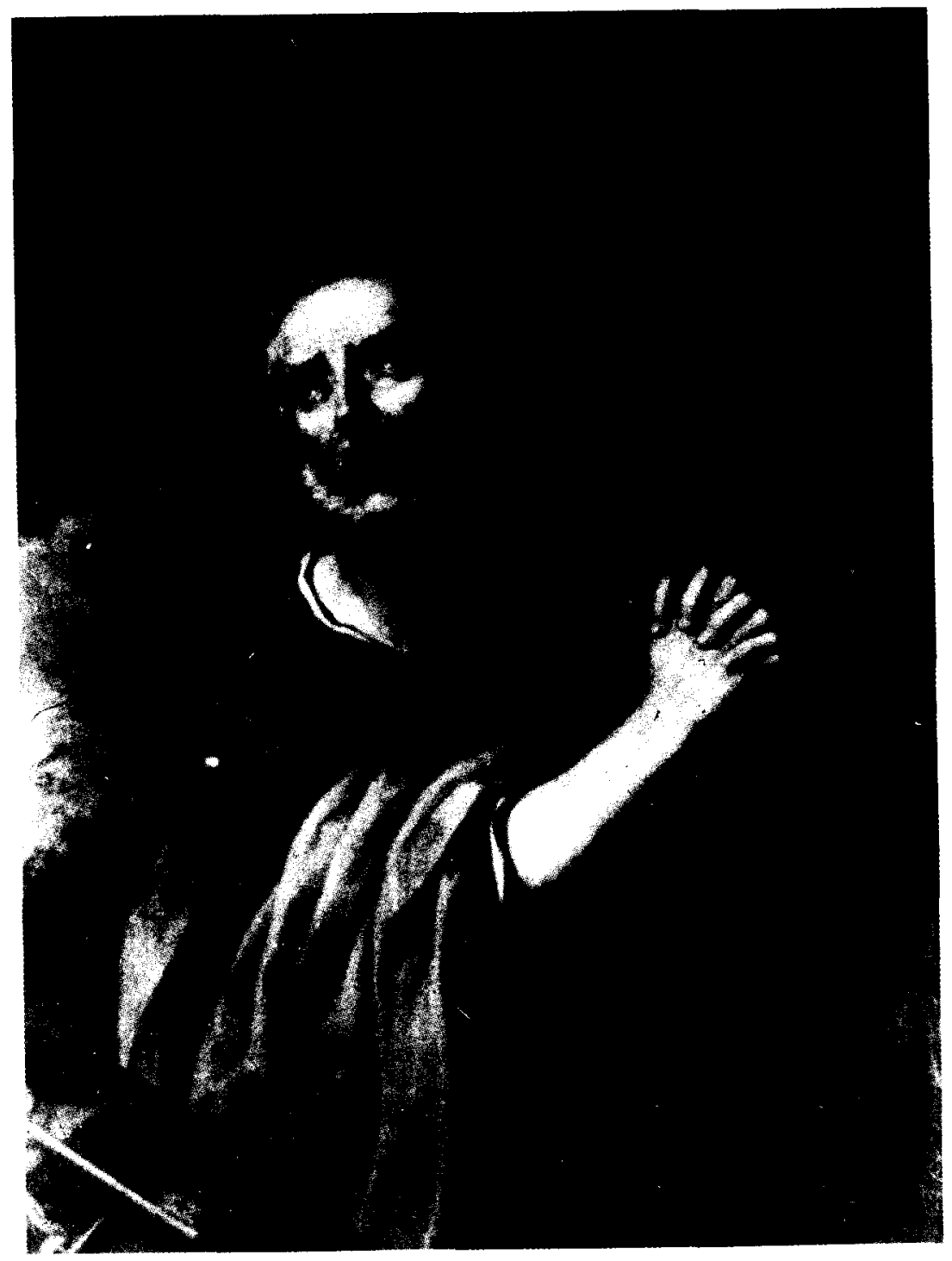

Fig. 19. Ribera, "San Pedro", Iglesia de la Caridad, Sevilla. 


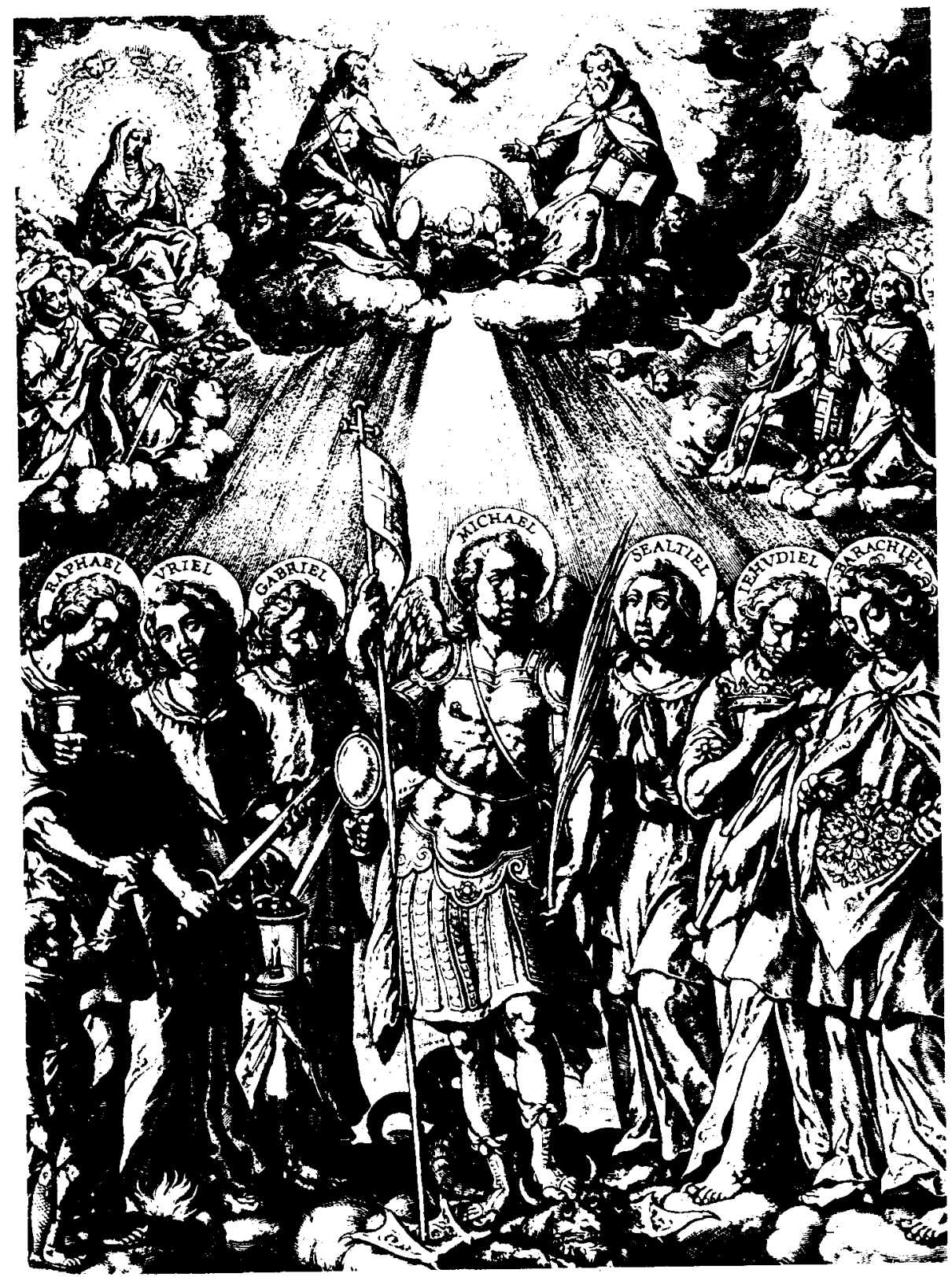

Fig. 20. "Arcángeles y querubes". Grabado de Jerónimo Wierx. 
Su iconografía, a pesar de estar bien determinada por los artistas, presentó un reto difícil de superar dado su propio carácter incorpóreo e invisible, de ahi que adoptarán la representación de un joven adolescente o un niño con túnicas de diferentes colores, con la cabellera corta en los niños y larga en los adolescentes. Su atributo esencial son las alas, que simbolizan su carácter de mensajeros, la velocidad y capacidad de penetración en cualquier sitio.

Es admitido desde antiguo por los teólogos y artistas que los ángeles se agrupan en nueve coros, subdivididos en tres órdenes: serafines, querubines y tronos, que son los más elevados en la jerarquia celeste y más cercanos a Dios; el segundo orden lo constituyen dominaciones, virtudes y potestades y por último el tercero de principados, arcángeles y ángeles.

Además de los nombres que los designaban existen una serie de caracteristicas que distinguen a unos de otros. Los más significados y con caracteres peculiares son también los más cercanos a los hombres: los arcángeles, cada uno con su personalidad característica y sus atributos, y los ángeles, que se aproximan a toda escena celeste o terrestre. Dentro de este carácter de los ángeles el hombre ha expandido el del ángel de la guarda. Peculiar singularidad ofrecen los querubines cuya representación se reduce a cabecitas aladas que aparecen en los rompimientos de gloria ${ }^{101}$.

Rara vez encontraremos esta composición constituyendo un tema único, asi como también será muy escasa la representación religiosa en la que no participen los ángeles, seres tan familiares al hombre, con cualquier pretexto u ocasión.

El segundo tema tratado corresponde a uel purgatorio con muchas almas y algunos ángeles en lo alto, en acción de estar sacando algunas, como ordinariamente se suele ver en algunas pinturas de este asumpto". El Purgatorio constituia el lugar donde permanecian las ánimas en espera de purificarse para acceder al cielo. Las ánimas suelen ser representadas como cuerpos desnudos emergiendo de las llamas, que pudieran confundirse con las infernales si no fuesen evidentes las actitudes orantes y las expresiones de los rostros serenos, confiados e incluso alegres, junto con

101 Pacheco, F., op. cit., 566-570; Reau, L., op. cit., II, 1, págs. 30-55; Male, E., El Barroco..., op. cit., págs. 261-263; PéREz Rioja, José Antonio, Diccionario de simbolos y mitos. Madrid 1971, págs. 65-66; CiRlot, Juan Eduardo, Diccionario de simbolos. Barcelona 1978, pág. 68; Morales y Marin, José Luis, Diccionario de iconologia y simbologia. Madrid 1984, págs. 4344; HalL, J., op. cit. págs. 36-37; ReviLLA, F., Diccionario de iconografia. Madrid 1990, págs. 31-32. 
la frecuente presencia en lo alto de la Virgen, los ángeles o algún santo protector aludiendo a la gloria del cielo.

Los protestantes negaban la existencia del purgatorio, asi como la necesidad de indulgencias para salvar estas almas porque Cristo ya habia redimido a toda la humanidad. La representación del Purgatorio parte de los dias de la Reforma y Contrarreforma. Los grabados consagrados a la misa de san Gregorio muestran almas del purgatorio pidiendo oraciones ${ }^{102}$. En Italia en la misma época un cuadro anónimo del municipio de Chieti representa a la Virgen haciendo fluir la leche sobre pequeñas almas rodeadas de llamas que emergen del seno de la tierra.

Sin embargo en estos ejemplos el purgatorio apenas está identificado. No entra en el arte hasta los últimos años del siglo XVI en la época de las grandes controversias religiosas. En Roma, en la capilla de los Ángeles, del Jesús, vemos una de las más antiguas representaciones, el fresco de Federico Zúccaro. El artista pone ante nuestros ojos una hoguera ardiendo y ángeles sumergiéndose en este mar de fuego sacan de allí pequeñas figuritas que son las almas y las ofrecen a Cristo y la Virgen. A veces es la Virgen sola la que acude al purgatorio en ayuda de las ánimas como en la representación del cuadro del altar de Santa María del Sufragio de Roma, de fines del siglo XVII. En esta obra las ánimas han abandonado diminutos cuerpos por unos más realistas grandes y desnudos. Los cuadros del purgatorio se multiplicaron en las cotradias que pedian por las almas.

La protección hacia las ánimas del purgatorio no siempre la ejercen la Virgen o Cristo, con frecuencia son sustituidos por santos, sacerdotes diciendo misas en su favor o ángeles. Estas escenas ocuparian la parte superior del lienzo.

Entre las representaciones podemos citar la de Alonso Cano del Museo de Bellas Artes de Sevilla ${ }^{103}$ que se puede considerar como una excepción al aparecer sólo las almas con rostros suplicantes entre las llamas. Protegidos por los ángeles son pintadas en los lienzos del Guercino ${ }^{104}$ y Rubens ${ }^{105}$.

La última cena corresponde, según el encargo, a la pintura de Todos los Santos. La fuente de esta representación se encuentra en el evangelio

102 Male, E., El Barroco..., op. cit., págs. 84-87; Pérez Rıoja, J. A., op. cit., pág. 362; Revilla,

F., op. cit., págs. 33 y 311 .

${ }^{103}$ Museo de Bellas Artes de Sevilla.

${ }^{104}$ San Gregorio y las almas del purgatorio, en San Paolo de Bolonia.

${ }^{105}$ Santa Teresa libera del Purgatorio el alma de san Bernardino de Mendoza, Museo de Bellas Artes de Amberes. 
de san Mateo (XXV, 31-46), cuando indica que Dios separará después del Juicio Final a los condenados de los elegidos y en la doctrina de san Agustín, según la cual, la «civitas dei», fundada por Abel y gobernada por Cristo, vive a medias entre el cielo y la tierra, mezclada con la "civitas terrena", fundada por Cain y gobernada por el demonio y sólo después del Juicio Final se establecerá el verdadero reino de Dios. Entre los elegidos se encuentran indudablemente los santos, que reciben su recompensa por haber vencido las dificultades terrenales y las tentaciones del demonio, y en virtud de estos méritos son dignos de estar en el $\mathrm{Pa}$ raiso.

A la hora de figurar este tema los artistas han establecido una serie de criterios y esquemas iconográficos a los que estaria próxima la obra de Miranda. Normalmente se suele incluir en esta visión celestial del $\mathrm{Pa}$ raíso y la Gloria, a la Trinidad: Padre, Hijo y Espíritu Santo, a los que acompaña en numerosas ocasiones la Virgen a la derecha de Cristo, todos ellos vestidos con túnicas blancas, símbolo de la pureza y limpieza. Muchos de los santos vestirán este atuendo, aunque en ocasiones también los pintores introducen otros colores en su vestuario para dar vivacidad y colorido a la composición. Alrededor de la Trinidad o en otros casos de la Virgen se sitúan rodeándoles todos los santos elegidos, dispuestos en circulos concéntricos o grupos que responden a las diversas categorias: patriarcas, profetas, vírgenes, santos, apóstoles, etc.

Característico suele ser el que se los rodee e inunde de luz que denota precisamente su santidad y pureza. Dos atributos propios de las representaciones celestiales han sido siempre la música y la luz. La primera viene sugerida normalmente por la presencia de ángeles cantores o con instrumentos musicales, mientras la segunda se pinta por medio de nubes coloreadas y rayos dorados y refulgentes, inundando toda la composición de luz. Los rostros de los presentes muestran la alegria y bondad de los bienaventurados, y presentan un aspecto angélico, ajenos por completo a la enfermedad y la vejez.

La composición se establece con arreglo a un eje central, donde se situa la Trinidad, Cristo o la Virgen, o todos ellos, y, a ambos lados, de forma simétrica se colocan grupos de santos. Esta representación creaba además otra serie de dificultades añadidas, como la gran cantidad de personajes a incluir, obligando en muchos casos a una reducción simbólica a unos cuantos de ellos, los más representativos para el comitente $u$ orden religiosa, etc. que encargase la obra. Este tipo de escenas ofrece 


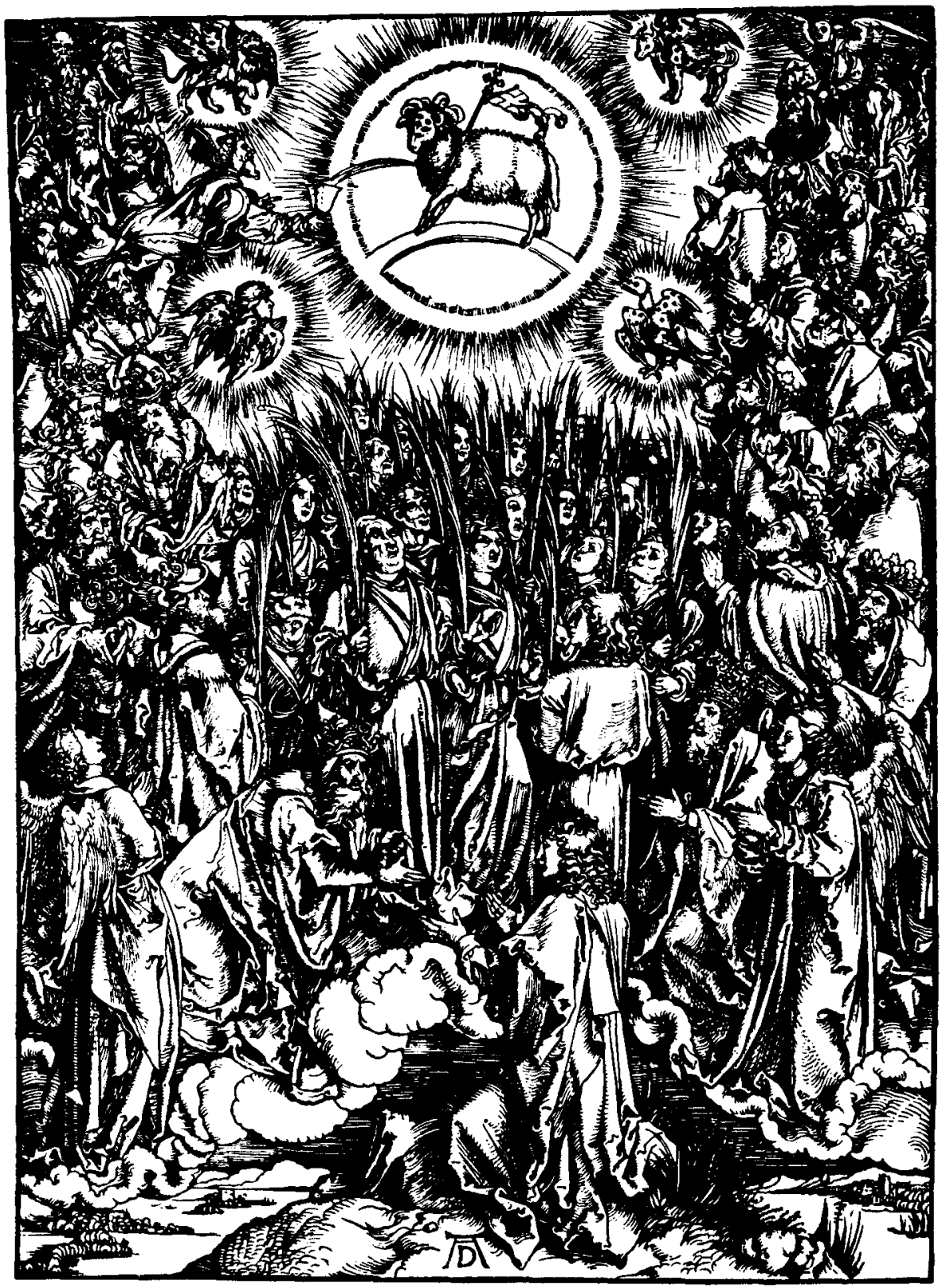

Fig. 21. Durero, "Todos los santos", grabado de la serie del Apocalipsis. 
muchas similitudes con composiciones de apoteosis de santos, coronaciones de santas, o de la propia Virgen, etc. ${ }^{106}$.

Para hacernos una idea de cómo podia ser la estructura básica de la obra de Miranda podemos evocar las imágenes pictóricas transmitidas acerca de este tema por Fouquet ${ }^{107}$, Van Eyck ${ }^{108}$, Giotto ${ }^{109}$, Durero ${ }^{110}$, Tintoretto ${ }^{111}$, etc.

Las pinturas de esta capilla del presbiterio, del lado de la epistola, enlazan iconográfica, temática y conceptualmente con todo el programa desarrollado en las naves de la iglesia, incidiendo en la salvación o condena de los hombres según su actuación, para concluir mostrando la visión gloriosa y triunfal de los bienaventurados y santos en la gloria.

Volviendo al altar mayor hemos de señalar que en el documento se indica que, además de las pinturas ya mencionadas, "se yncluyen para este retablo maior tres pinturas pequeñas que han de seruir para la puertecilla del frente y de los dos costados del Sagrario de Altar Mayor las quales an de ser yguales en alto y ancho de suerte que lo alto de cada una sean dos varas y su ancho de una; los assumptos de las tres puertas seran el Santissimo Sacramento de la Eucaristia respecto de circundarla en dicho Sagrario e ynteligenzia de que la pintura de el medio que hace frente bastará que este pintada por su exterior respecto de que no se ve su interior auiendose de bajar y subir por medio de un torno; pero la de los Costados aunque se suban y bajen ygualmente abran de tener por la parte interior algun adorno de flores y Angeles para que cuando su Diuina Magestad este presente se vean dhos adornos de flores y Angeles y la puertezilla del Sagrario del Copón con el Buen Pastor y en el hueco del obalo del Altar maior el escudo de armas de tra. Sra. de Guadalupe".

La iconografía del Buen Pastor tiene sus fuentes documentales en la Biblia, donde se alude a Cristo y a los cristianos como al pastor y a las ovejas, pero principalmente podemos resaltar las parábolas de Lucas (15, 3-7) y Juan (10, 1-18), asi como el Salmo 23, Ezequiel (34) e Isaias (40, 11). Debemos indicar, antes de proseguir, que Cristo aúna en su persona la doble vertiente, pues unas veces figura como el pastor que guía a las

\footnotetext{
${ }^{106}$ Interian de Ayala, J., op. cit., t. II, págs. 445-446; Reau, L., op. cit., II, 2, págs. 750-756; Male, E., L'Art religieux de la fin du Moyen Age, op. cit., págs. 475 y ss.

${ }^{107}$ Miniatura de las Horas de Etienne Chevalier, Chantilly.

${ }^{108}$ Políptico del cordero mistico san Bavón de Gante.

109 Santos Bienaventurados y los ángeles, Poliptico Baroncelli.

${ }^{110}$ Adoración de la Santisima Trinidad (Adoración de Todos los Santos), $135 \times 123 \mathrm{~cm}$, fechado en 1511, Museum Kunsthistorisches de Viena

"1" Palacio Ducal de Venecia, $700 \times 2.200 \mathrm{~cm}$, y un boceto en el Museo del Louvre de Paris.
} 
ovejas, la Iglesia y los cristianos, y en otras ocasiones se convierte Él mismo en el cordero que va a ser inmolado. La imagen de Jesús como pastor hunde sus raíces en el modo de vida nómada característico del pueblo de Israel, donde el pastoreo jugaba un papel esencial en su supervivencia, de ahí que identifiquen a su Dios con una imagen habitual para ellos como el pastor.

La imagen de Cristo como Buen Pastor aparece en los primeros siglos del arte cristiano. Son abundantes sus representaciones en las catacumbas, mosaicos y sarcófagos, pero, con la llegada de la Edad Media, se extingue esta figuración, que reaparecerá de nuevo con la Contrarreforma presentando algunas variantes, siendo la más significativa en nuestro pais la representación del Buen Pastor, como niño, en vez de joven o adulto, como era lo establecido. El Buen Pastor suele aparecer configurado en dos escenas, principalmente. Una en la que se le efigia sentado en una roca apacentando su rebaño. En ésta habitualmente presenta el aspecto de joven, sin barba o bien barba corta, con su bastón o cayado, y tocando incluso una siringa o lira, imagen que indudablemente guarda estrecha relación con el Orfeo clásico, encantador de animales. La otra imagen es la del pastor con la oveja sobre los hombros, el "Buen Pastor" que va en busca de la oveja perdida para restituirla al rebaño, que también constituye una adaptación de un prototipo pagano, el de Mercurio, guardián de los rebaños y de los moscóforos griegos. La oveja rescatada y devuelta al rebaño simboliza al pecador arrepentido. Por tanto, con esta imagen se está insistiendo a los fieles en la necesidad del arrepentimiento, aludiendo explícitamente al sacramento de la Penitencia como camino de redención y reconciliación con el resto de los cristianos, mostrándonos a Cristo como guia en ese camino ${ }^{112}$.

Son varias las obras artísticas en que se refleja la escena de Cristo como Buen Pastor. Entre ellas, podemos citar, además de la conocida estatua del Museo de Letrán, las de Murillo ${ }^{113}$, Cristóbal García Salmerón ${ }^{114}$, Vicente López ${ }^{115}$, Pedro Ruiz González ${ }^{116}$, la de un anónimo español del siglo XVII ${ }^{117} \mathrm{y}$ otro del XVIII ${ }^{118}$, etc.

${ }^{12}$ Reau, L., op. cit., Il, 2, págs. 31-35, 338-339; Hall, J., op. cit., págs. 247-248; Revilla, F., op. cit., págs. 292-293.

${ }^{113}$ Óleo sobre lienzo, $123 \times 101 \mathrm{~cm}$, Museo del Prado, Madrid, núm. inv. 962.

114 Oleo sobre lienzo, $222 \times 269 \mathrm{~cm}$, Museo del Prado, Madrid, núm. inv. 3.280 y en el mismo museo otra obra de $140 \times 107 \mathrm{~cm}$, nüm. inv. 6.085 .

115 Tabla, $23 \times 17 \mathrm{~cm}$, propiedad del Museo del Prado, depositado en el Museo de Málaga, núm. inv. 7.523 .

${ }_{116}$ Tabla, $201 \times 87 \mathrm{~cm}$, Museo del Prado, Madrid, núm. 4.558.

11 Tabla, $47 \times 36 \mathrm{~cm}$, Museo del Prado, Madrid, núm. inv. 5.207 .

${ }^{118}$ El Divino Pastor apacentando a los corderos, Tabla $146 \times 62 \mathrm{~cm}$, Museo del Prado, 
Las armas de Nuestra Señora de Guadalupe, situadas en el óvalo del altar mayor, consisten en un jarrón con azucenas, alusivas a la pureza e integridad de la Virgen. Se encuentran repetidas por diversas partes del conjunto monástico proclamando sus virtudes y su presencia por doquier.

Para concluir con los encargos realizados por el duque de Veragua a Juan Garcia de Miranda para esta iglesia hay que aludir al compromiso que éste asume de realizar " 17 frontispicios pintados en lienzos con bastidores de la medida regular de Altares para los 17 que ha de tener la dha. nueua Iglesia, cuyos 17 frontispicios han de ser pintados con flores de la misma manera y forma que los que se hallan en la Iglesia de don Juan de Alarcón desta Corte. Poniendo tambien en el medio de cada uno de ellos su targeta correspondiente al numero o assumpto del quadro de cada Altar que quedan esplicados y esta segunda obra de los 17 frontispicios los ha de ejecutar en el mismo termino de dichos dos años y en el precio y cantidad de 60.120 reales de vellón que corresponden a seis doblones de a 60 reales para cada uno, arreglándose en cuanto a la calidad de buenos colores a lo mismo que queda expresado por las Pinturas, exponiendo su obra al examen de Peritos en el caso de que parezca no auer satisfecho con esta obligación conforme a lo estipulado".

La colocación de estas tarjetas explicativas de los temas representados, refleja un interés por transmitir a todo tipo de espectadores la escena pintada. Este recurso es también utilizado para los lienzos de Zurbarán en la sacristia de este monasterio cuyos comentarios se deben al padre Juan de Toledo.

Ante un programa tan complejo no debemos concluir el capítulo sin realizar un compendio que nos proporcione la clave y sentido de todo el conjunto. Lamentablemente, desaparecidos los lienzos, excepto uno de ellos, el de la Encarnación, solamente a través del inapreciable valor del documento hemos podido reconstruir su contenido. Es penoso que, habiendo llegado hasta nuestro siglo, tras los duros avatares históricos y, teniendo testimonio de su existencia a través de personas que los contemplaron «in situ», hoy sea imposible, hasta el momento, su localización. Esta secuencia pictórica presenta un relato simbólico que tiene, como telón de fondo, el tiempo histórico de la salvación e intervención salvífica de Dios asi como la misión redentora de su Hijo Jesucristo, y la acción expansiva del Espiritu Santo que confirma nuestra tesis interpretativa del programa iconológico.

${ }^{118}$ El Divino Pastor apacentando a los corderos, Tabla $146 \times 62 \mathrm{~cm}$, Musso del Prado, Madrid, núm. inv. 6.087. 


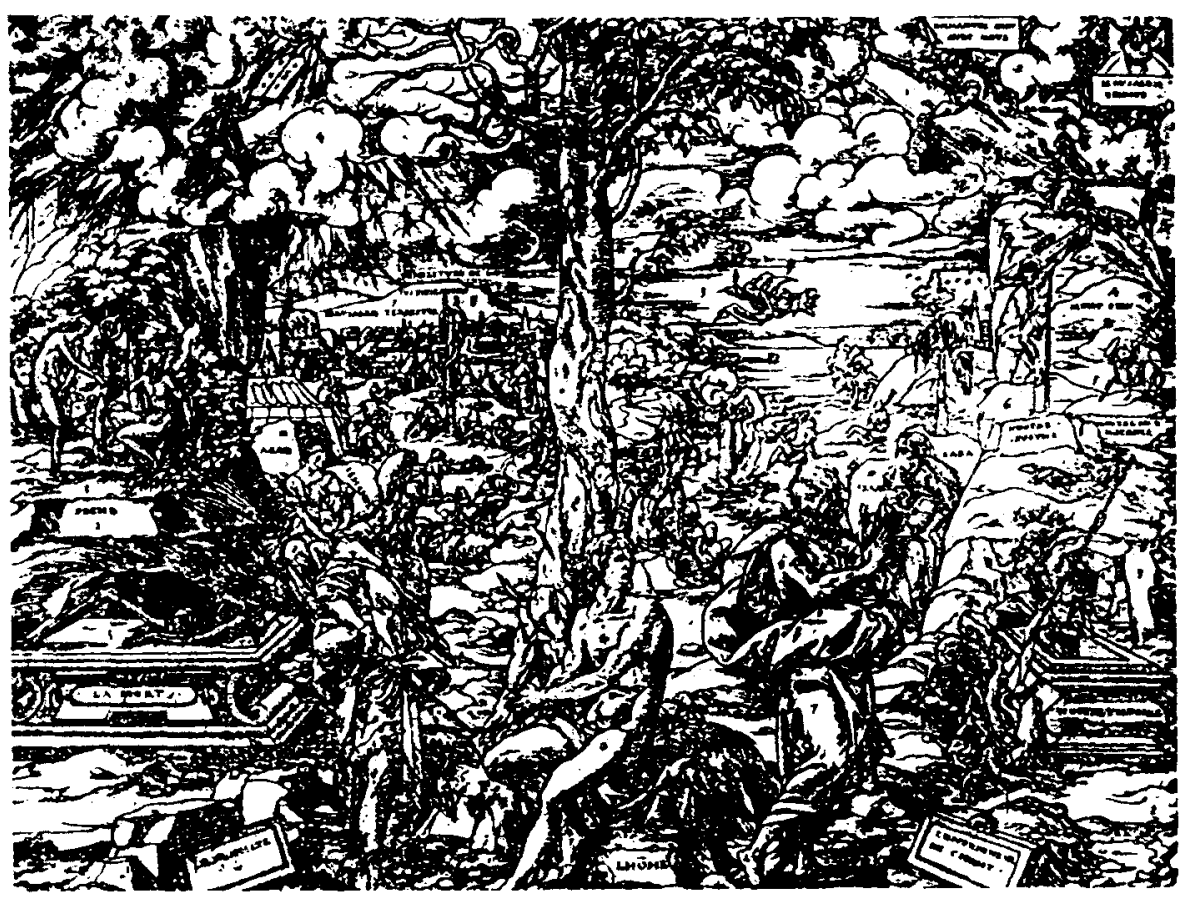

Fig. 22. Geoffroy Tory, "El hombre entre el pecado y la redención".

La trascendencia y sentido de todo este programa iconográfico es recogido también en otras obras, tanto protestantes como católicas, que insisten de forma relevante sobre el pecado y la muerte, que entraron en el mundo por la falta del hombre, y que fueron vencidas por un Redentor. Citamos sólo una, aquélla de la que muchas parecen derivar, la creada por Geoffroy Tory en su grabado El hombre entre el pecado y la Redención ${ }^{119}$. En medio de un gran paisaje aparece un hombre desnudo, en representación del “Hombre». Está hundido bajo el peso de su falta y, no lejos de él, se ven sus obras: el Pecado y la Muerte. Solo, miserable y desnudo, caeria en la desesperación si dos hombres no se le aproximasen: el Profeta, que le anuncia al salvador que va a venir, y san Juan Bautista que le afirma que este salvador ya ha venido. $Y$, en efecto, a la derecha se divisa la “Encarnación», que una inscripción titula «la Gracia». Más lejos, Jesucristo muere en Cruz, que es, según la inscripción "Nuestra Justicia». El Cordero porta el estandarte: éste es «Nuestra Inocencia».

119 Grabado del siglo xvi. Bernard, Auguste, Geoffroy Tory, 1865, pág. 324 (tomado de MALE, L'art religieux de la fin du Mayen Age, op. cit., págs. 284 y 286). 
Un programa iconológico perdido, recuperado. Pinturas de la ...

Jesús resucitado sobre la tumba, aplasta a sus pies la Muerte y el Demonio: ésta es "Nuestra Victoria».

Estas creaciones son propias de grandes conjuntos monásticos y religiosos como el Hospital de la Caridad de Sevilla, Cartuja del Paular en Madrid, San Diego de Alcalá de Henares, etc. 
